Dan D. Y. Shapira

Open University of Israel, Ra'anannah

\title{
"TABERNACLE OF VINE»: SOME (JUDAIZING?) FEATURES IN THE OLD GEORGIAN VITA OF ST. NINO
}

St. Nino, «Mother of the Georgians», the traditional illuminator of Georgia $^{2}{ }^{2}$ is believed to have brought Christianity to Eastern Georgia around 335 (her memory is celebrated on January 14th); Coptic and Byzantine writers of later dates called her theognosté, «she who made God known» to the Georgians. ${ }^{3}$ The Old Georgian Vita of St. Nino forms a part of Conversion of Georgia [henceforth: MK], ${ }^{4}$ which served as one of the sources of the Geor-

${ }^{1}$ This article is mostly based on two papers read at the Institut für Iranistik (Freiuniversität, Berlin), 10th December 1994, and at the Eighth Caucasian Colloquium, Societas Caucasologica Europaea, University of Leiden, $7^{\text {th }}$ June 1996 . Earlier versions of this paper were read by Prof. Konstantin Lerner, Prof. Shaul Shaked, Prof. Michael Stone, by Dr. Mordechai Even-Vered, Mr. Michael Shneider (the Hebrew University of Jerusalem), Mr. Reuven Kipperwasser (Bar-Ilan University), Fr. Gregory [V. M.] Lourié (St. Petersburg), Prof. Ora Limor and Mr. Uri Gershovich (The Open University of Israel). I am very grateful to these persons for their remarks and insights. All the shortcomings are, of course, mine.

${ }^{2}$ In fact, of Eastern Georgia, Kartli; Western Georgia, Lazica, was Christianized by King Tsate and the Byzantine Emperor Justinian (527-565) only in 523, although at least one city, Pytyus (Pityonte, Georgian Bičvinta, Russian Picunda) had a bishop as early as in 325 .

${ }^{3}$ Cf. now M. van Esbroek, Nino, Théognosta et Eusthate: un dossier hagiographique oriental des IVe-Ve siècles (forthcoming). See also M. VAN EsBroEK, Le dossier de sainte Nino et sa composante copte // Santa Nino et Georgia. Storia e spiritualitácristiana nel paese del Vello d'oro. Atti del I Convegno Internazionale di Studi Georgiani. Roma 30 gennaion 1999 / Ed. G. Shurgaia (Roma 2000) 99-123 (the volume reviewed by A. Muravjev in XB 3 (IX) (2002) 521-523).

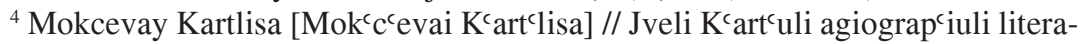
turis jeglebi [Relics of Old Georgian Hagiographical Literature]. I / Ed. I. Abulaje (Tbilisi, 1964) 81-163. For a new edition of the text, Cf. the recent Hebrew book by K. Lerner, The Chronicle The Conversion of K'art'li (Jerusalem, 2003). It should be observed that in this book no Georgain original appears, and in this article, a computerized version, without references to pages, is quoted. It should be noted as well that the Hebrew translation and indices of the Biblical quotations in K. Lerner's book were prepared by D. Shapira. The older editions and translations: E. C. ТАКАшвили, Обращение Грузии // Сборник материалов для описания местностей и племен Кавказа XXVIII (1900); cf. O. WARDROP, Life of S. Nino // Studia Biblica et ecclesi- 
gian Chronicle [henceforth: $\mathrm{KC}] .^{5}$ The two collections are compiled of compositions of different character and date, such as, for example, the oldest Georgian chronicle preserved in MK as a part of it is attributed to one deacon Gregory, and perhaps goes back to the seventh century. The whole of the Vita of St. Nino found in MK was edited in the ninth century, but the sources of the compiler go back to material written at least as early as the seventh century. ${ }^{6}$ The question of interrelationship between $\mathrm{MK}$ and $\mathrm{KC}$ will not be dealt with here; however, it is worth notice that Leonti Mroveli, the redactor of $\mathrm{KC}$ proper (which forms only one of the parts of $\mathrm{KC}^{7}$ ), was placed in the eighth

astica 1 (1909) 1-66; D. M. LANG, Lives and Legends of the Georgian Saints (London, 1956) 13-39; see also G. PÄтsch, Die Bekehrung Georgiens Mokcevay Kartlisay (Verfasser unbekannt) // Bedi Kartlisa. Revue de kartvélogie 33 (1975) 288-337. For theoretizing about a Jewish setting, cf. T. Mgaloblishvili, I. Gagoshidze, The Jewish Diaspora and Early Christianity in Georgia // Ancient Christianity in the Caucasus. Iberica Caucasica. Vol. 1 / Ed. T. MgaloblishviLi (Richmond, 1998) (Curzon Caucasus World) 39-58. Compare also J. van OORT, Judaeo-Christianity: the Rôle of the Hebrew Diaspora in the Origin of Christianity in the Roman North Africa // Proceedings of the International Symposium: Early Christianity and Georgia. Tbilisi, Mtsxeta, October 1991 (Tbilisi, 1992) 1-22; J. van OORT, Jewish Elements in the origin of North African Christianity // Ancient Christianity in the Caucasus. Iberica Caucasica... 97-105; M. van Esbroek, La place de Jérusalem dans la «Conversion de la Géorgie» // Ancient Christianity in the Caucasus. Iberica Caucasica... 59-74; K. TSERETELI, Armazian Script // Ancient Christianity in the Caucasus. Iberica Caucasica... 155164. A new, older version of MK was recently found at St. Catahrina.

${ }^{5}$ Картлис Цховреба [K'art`lis C`xovreba]. I-II / Ed. S. QAuXcšIšVILI (Tbilisi, 1955); quoted (vol. I) as KC. See also F. Brosset, Histoire de la Géorgie depuis l'Antiquité jusqu'au XIXe siècle (St Petersburg, 1856); cf. also W. E. D. Allen, History of the Georgian People (London, 1932; repr.: New York, 1971); G. PÄтsch, Das Leben Karli's. Eine Chronik aus Georgien, 300-1200 (Leipzig, 1985); R. W. Thomson, Rewriting Caucasian History. The Medieval Armenian Adaptation of the Georgian Chronicles. The Original Georgian Texts and the Armenian Adaptation / Transl. with Introd. and Comm. (Oxford, 1996). On Georgian literature in general: M. TARCHNISHVILI, Geschichte der kirchlischen georgischen Literatur (Vatican, 1955); G. DEETERS, Georgische Literatur // Handbuch der Orientalistik, Abt. 1. Bd. 7: Armenisch and kaukasische Sprachen (1963) 129-155; K. SALIA, La littérature géorgienne // Bedi Kartlisa. Revue de kartvélogie. Vol. 17-26 (1964-1969), esp. Vol. 17-18 (1964) 2861; H. FÄHnRICH, Die georgische Literatur (Tbilisi, 1981); R. BARAMIDZE, Die Anfänge der georgischen Literatur // Georgica (Jena, 1987) 39-43; D. RAYFIELD, The Literature of Georgia. A History (Oxford, 1994).

${ }^{6}$ The Šatberdi MS is from 973 CE. For dating the older strata of this composition, cmp. Z. AleKsidze, Sur le vocabulaire de la Conversion du Kartli: miap 'ori, niap ori ou minap ori? // From Byzantium to Iran. Armenian Studies in Honour of Nina G. Garsoïan / Ed. J.-P. MAнÉ, R. W. Thomson (Atlanta, GA, 1997) 47-52.

${ }^{7}$ Only two or three (the first, the second, and probably, the fourth) of the six parts of $\mathrm{KC}$ were edited by him. 
or the eleventh century, ${ }^{8}$ while the History of the King Vaxtang Gorgasal, another composition also found in $\mathrm{KC}$ (the third part) and describing the events from the 5th-6th centuries, was written in the eighth or the ninth century. The final redaction of $\mathrm{KC}$ was made only in the 18th century in Moscow, by the exiled Georgian carevičs (Russian for «prince-of-blood») Vahušti (or, Vaxušti) Bagrationi (Bagration).

As noted by many scholars, the version of the Vita of St. Nino in MK, as compared to that of $\mathrm{KC}$, preserved numerous traits going back to the period of the Georgian history in which her Christian tradition was not yet finally fixed. Here some episodes allegedly reflecting this primitive stage of the Georgian Christianity will be dealt with.

Georgian traditions attribute the Christianization of Georgia exclusively to St. Nino and to her pupils, members of the local Jewish community (stressing the role of the female followers). Later, the so-called «Syriac fathers» were credited with establishment of Christian institutions. Nevertheless, the Georgian historical memory could not have ignored the all-too-obvious role played by St. Gregory the Parthian, the Illuminator (Lousaworičc, o $\varphi \omega \sigma \tau \eta ́ \rho)$ of the Armenians, ${ }^{9}$ and the legendary figure of St. Nino, whose name is attested not earlier that the seventh century, served with the Georgians to combine, or «to telescope», various layers of traditions about the early stages of the Georgian conversion. So she was said to be the daughter of Zaboulon / Zabilon of Cappadocia (who is said to vanquish the Branjis ${ }^{10}$ at the ${ }^{*}$ Catalaunian Fields ${ }^{11}$ and to baptize them thereafter!), to be brought up in the Armenian community in Jerusalem, she speaks Armenian and the language of the Jews, ${ }^{12}$ has links

${ }^{8}$ K. KeKelidze (K’. K’EK’ELIJE), Jveli kartuli lit’erat’uris ist’oria. I (Tbilisi, 1960) $236 \mathrm{ff}$., dated the work as written in the 1070s.

${ }^{9}$ The literature on the subject is extensive, cf., e. g., P. PeEters, Les débuts du Christianisme en Géorgie d'après les sources hagiographiques // AB 40 (1932) 5-58. As to the term «ulluminator» and its Greek and Georgian parallels foreign to the normal Armenian usage, cf. Н. МАРр, Крещение армян, грузин, абхазов и аланов святым Григорием (арабская версия) // Записки Восточного Отделения (thereforth 3BO) XVI [1904-1905] (1906) 63-212, s. 151-152.

${ }^{10}$ Apparently, a later distortion for *Franks, cf. Н. МАРр, Боги языческой Грузии по древне-грузинским источникам // 3BO XIV (1902) 28; cf. also H. MAPP // 3BO (1907) 319; the Huns of Attila are meant, of course, contaminated with the later legends about Chistianization of Gallia from Cappadocia, cf. Ibid. 319-323.

$11 * 451 \mathrm{CE}$ ! KC and MK spell it Patalan; was this Zabilon modeled on Bacurius, the Georgian prince and Roman general, the source (circa $380 \mathrm{CE}$ ) of the information of Rufinus (circa $403 \mathrm{CE}$ ) on the captiva (*St. Nino) who had converted Kartli? For Bacurius, cf. Rufinus, 10.11, 1.33 (The Chruch History of Rufinus of Aquileia. Books 10 and 11 / Transl. by Ph. A. Amidson, S. J. (Oxford, 1997) 20-23, 88).

${ }^{12}$ Which seems to be Aramaic, though the compiler meant Hebrew, the language of the Bible. KC 95.1 is less implicit about her speaking this language, and one is 
to the first Patriarch of Jerusalem, Jubenal $(422-458)^{13}$ and St. Helene ${ }^{14}$ (and even some vague ones to St. George the Cappadocian Soldier!), is connected to Armenian virgin martyrs Rip'simē, Gayanē and others (who are commemorated on October 5th and whose connection to St. Gregory the Parthian is a subject to debates).$^{15}$ In other words, she represents simultaneously the JudeoChristian, Armenian, Cappadocian, Jerusalemite and Byzantine origins of Georgian Christendom. In Georgian scholarship of the last decades there is a tendency to consider frequent references to Jews or Jewish traditions scattered in $\mathrm{MK}$ and $\mathrm{KC}$ as a proof of millennia-long ties between Jews and Georgians, and these texts were even used, by the Georgian hosts, several years ago, during official visits of high Israeli officials to Tbilisi, to cement the relations between two nations. The view of MK as a Judeo-Christian document of early times has received recently some support from other quarters, too. Nevertheless, in this author's opinion, the Georgian accounts about St. Nino can be understood mostly against the background of the Armenian traditions about the conversion of Armenia - and Iberia and Albania — by St. Gregory and the problematic traditions about the Armenian holy virgins, and I have plans to publish my investigation of this subject on another occasion. ${ }^{16}$ However, on this stage the importance of the study of the vocabulary and imaginery of St. Nino accounts must be emphasized, and here we have a good parallel with the case of St. Gregory the Parthian as reflected by the testimonies of Agat'angełos / Agathangelos and Vita Gregorii. ${ }^{17}$ Neverthe-

inclined to think (cf. Thomson, Rewriting Caucasian History... 103) that she was learning Hebrew.

${ }^{13}$ Who is said to «have the hope of all Christians in the Church of the Holy Resurrection (Anastasis)» and to pray there; Anastasis, built in 543, was the focus of Chalcedonite sympathizers, cf. B. М. Лурье [V. M. Lourí́], Из Иерусалима в Аксум через храм Соломона: архаичные предания о Сионе и Ковчеге Завета в составе Кебра Негест и их трансляция через Константинополь [From Jerusalem to Aksum through the Temple of Solomon: archaic traditions related to the Ark of Covenant and Sion in the Kebra Nagast and their translation through Constantinople] // XB 2 (VIII) (2001) 137-207, s. 176.

${ }^{14}$ According to KC $80-81$, St. Nino not only has baptized R'ipsimē (see further), but even almost converted St. Helene!

${ }^{15}$ On the Armenian side, [pseudo]Movses Xorenac ${ }^{c} i$ in the tenth century was the first to connect St. Nino (Nunē) with Rip'simē and Gayanē, apparently under the impact of the already recorded Georgian traditions.

${ }^{16}$ D. SHAPIRA, Old Georgian Echoes of the Armenian Agathangełos Cycle (forthcoming).

${ }^{17}$ See, e. g., G. GaritTe, Documents pour l'étude du livre d'Agathange (Citta del Vaticano, 1946); G. Widengren, Sources of Parthian and Sasanian History // The Cambridge History of Iran 3 (2): The Seleucid, Parthian and Sasanian Periods / Ed. Ehsan Yarshater (Cambridge-London etc. 1983) 1261-1283; G. WinkLer, Our Present Knowledge of the History of Agat'angełos and its Oriental Versions // Réarm 
less, the St. Nino traditions are no more historical than, e. g., those of the Ethiopian Kebrâ Negâst, ${ }^{18}$ and they should be studied, as a whole, in a general context of the split with the Armenian Mother Church in the early 7th century, and, as a consequence, of building an alternative, Judaizing, set of traditions claiming for the apostolic status of the Georgian Church. ${ }^{19}$

NS 14 (1980) 125-141. This work was composed of several independant parts put together after 456 CE (WINKLER, Our Present Knowledge of the History of Agat'angełos... 125: after 450-451), Agathangelos has Faustos Buzand as one of its major sources (R. W. Thomson, Agathangelos: History of the Armenians (Albany, NY, 1976) xvi). Winkler (Our Present Knowledge of the History of Agat'angełos... 137) stated that these texts «show tendentious insistence on the connections of Grigor with Cappadocia, and this despite the overwhelming traces of ties with Syria... Prior to the Christianization of Armenia through Cappadocia, there must have been a strong missionary activity from Syria which has come down to us only in obscure legendary reports, and which only can be detected through a careful investigation of the vocabulary...».

${ }^{18}$ C. Bezold, Kebra Nagast, Die Herrlichkeit der Könige. Nach dem Handschriften in Berlin, London, Oxford und Paris zum ersten Mal im äthiopischen Urtext hrsg. und mit deutscher Uebersetzung versehen (Münich, 1905); D. A. HubBard, The Literary Sources of the Kebra Nagast (The University of St. Andrews, 1956), a PhD Thesis under supervision of Prof. E. Ullendorf; I. SHAHID, The Kebra Nagast in the Light of Recent Research // Mus 89 (1976) 133-178; cf. also the important study, B. М. ПлАтонов, Кебра Нагаст (Основные идеи эфиопского династического романа XIV в.) // Палестинский сборник 28 (91), (1986) 45-50. Cf. now ЛурьЕ, Из Иерусалима в Аксум через храм Соломона... 137-207.

${ }^{19}$ Judaizing tendencies were prominent in many of the national churches outside the Roman Empire, and in Armenia they were perhaps no less significant than in Aksum: beside legends, of a later date, about Jewish descent of certain noble families, we should ennumerate the legendary origin of the Armenian Arsacids from Abraham and Keturah, remnants of royal polygamy, hereditary character of the office of the head of the Church, later called «catholicos», and of the bishops, etc. Both Armenian and Georgian literacy began to flourish around the mid-5th century; until then, their languages of religious education were Syriac or Greek. It was in the context of the struggle against Nestorius and his views that the national scripts were invented, apparently, by St. Mesrop (cf. P. PeETERs, Jérémie, évèque de l'Ibérie perse (431) // $A B$ 41/1-2 (1933) 5-33). Fighting against the armies of Yazdigird II the Sasanian, the Armenians and Georgians did not participate actively in the Council of Chalcedon in 451 and did not endorse the decisions made there, wrongly identifying them later with the teachings of Nestorius (cf. W. H. C. FrEnd, The Rise of the Monophysite Movement. Chapters in the History of the Church in the Fifth and Sixth Centuries (Cambridge University Press, 1979 (1972 $\left.{ }^{1}\right) 313$. It should be remembered that Nestorius' supporters believed that their views were vindicated by the Chalcedon Counsil.) Another reason for the Armenian rejection of Chalcedon was purely linguistic: the Armenian, at that time, had only one term, pnout iwn, for both physis and hypostasis, and only much later a new term for physis, ew iwn or koioutiwn, was coined). 
They accepted the compromising Henotikon of the Emperor Zeno (481/2CE) under the Katholikos Babgen (490-515), apparently, in 491 (cf. now also Н. Г. ГАРсоян, Был ли Собор в Валаршапате в 491 году? // XB 2 (VIII) (2001) 116-120), but when the Imperial Church returned to the Chalcedon formula in 518, they rejected it, and in 554 or 555 the Greek Church itself - apparently, on hierarchial basis, — not only her doctrine, was anathematized at the Second Duin Synod under the Katholikos Narsēs II (548-557). Beginning from 591, Persarmenia, Albania and Kartli were under direct Persian domination, and the Byzantine established a Chalcedonite Armenian Catholicosate at Awan, to confront the Monophysite one at Persian Duin (Н. Г. Адонц, Армения в эпоху Юстиниана. Политическое состояние на основе нахарарского строя (Ереван, 1971) 343-344; В. А. АрутюновА-ФидАнян, Армяно-византийская контактная зона (X-XI вв.). Результаты взаимодействия культур (Москва, 1994) 60-61). In 606-608, the Georgians, under their Katholikos Kyrion, adopted Byzantine Orthodoxy, to which they had been inclined since the late 6th century, and it was then that the deep cultural split between the Armenians and the Georgians began, after Abraham I the Armenian (607-615) excommunicated Kyrion and the Geor-

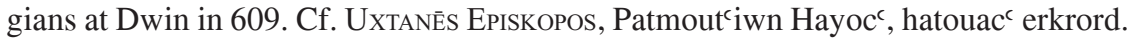

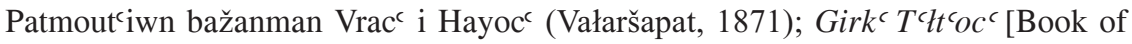
Letters] / Ed. Y. IzMEREANC' (Tiflis, 1901) (translation of the material relevant for this discussion in: N. GARSOÏAN, L'église arménienne et le grand schism d'Orient (Lovanii, 1999) (CSCO 574; Subsidia 100) 516-583; see also pp. 355-398); L. MELIK' SẼT $^{\text {c }}$ BEK, Vrac ${ }^{`}$ ałbyournerə Hayastani i hayeri masin (Erevan, 1934); UXTANESI, Ist’oris gamoq’opisat Kartvelta da Somextgan / Ed. Z. AleKsidze (Tbilisi, 1975) [non vidi]; Arseni Sapareli, Ganq'opisatwis Kartvelta da Somexta [The Split between Georgia and Armenia] / Ed. Z. AlEKsidze (Tbilisi, 1980). However, there were also numerous Armenian Chalcedonians, primarily, within the Empire (Byzantine Armenia); though the literature on this subject is vast, one may be referred to the classical article by Н. Я. МАрР, Аркаун, монгольское название христиан в связи с вопросом об армянах-халкидонитах // BB 12/1-4 (1906) 1-68, now republished in Кавказский культурный мир и Армения (Ереван, 1995) 209-276; А. П. КАждАн, Армяне в составе господствующего класса Византии XI-XII вв. (Москва, 1974) 145 ff.; see now АрутюновА-ФидАнян, Армяно-византийская контактная зона...; cf. also, e. g., V. A. Arutunnova-Fidanuan, The Ethno-confessial Self-awareness of Armenian Chalcedonians // Réarm 21 (1988-1989) 345-363; see also В. П. СтеПАненко, Пакурианы в Византии. К дебатам об этнической принадлежности т. н. армяноиверских фамилий // XB 2 (VIII) (2001) 255-276. An important Armeno-Chalcedonite source from the 7th century is Narratio De Rebus Armeniae (see G. GARITTE, La Narratio De Rebus Armeniae (Louvain, 1952) (CSLO 132, Subsidia 4); compare now G. GaRITTE, La source grecque des «Trente articles» géorgiens contre les Arméniens // Handes Amsorya 1-2 (1976). On Armenian Chalcedonites in the land of Vr'kan (Kartli, Georgia) marzpanate who refused to become converted to Monophy-

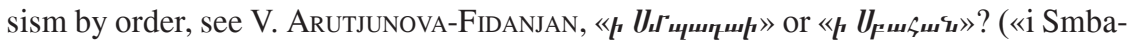
tai» or «i Spahan»? Sebēos, ch. 25) // From Byzantium to Iran. Armenian Studies in Honour of Nina G. Garsoïan / Ed. J.-P. Mahé, R. W. Thomson (Atlanta, GA, 1997) 151-164, esp. 161-162. On Armeno-Georgian Church relations in the 6th century, cf. important rematks in: M. TARCHNIŠVILI, Sources arméno-géorgiennes de l'histoire 
First, Rip'simē, Gayanē, St. Nino and others 50 (or 49, i. e. 50 except Nino $)^{20}$ holy virgins, having been expelled from the Roman Empire, ${ }^{21}$ ar-

ancienne de l'église de Géorgie // Mus 60 (1947) 29-50, and in: B. Martin-Hisard, Jalons pour une histoire du culte de Sainte Nino (fin IVe-XIIIe s. // From Byzantium to Iran... 53-78, s. 69-70. Under Monothelite Heraclius, the Armenian Church reunited though with the Catholic (629), but after the Arab Muslim onslaught, they relapsed into their national church and again denounced Chalcedon at Dwin in 645. But the final separation followed only the Manazkert Synod of 726, see Адонц, Армения в эпоху Юстиниана... 338; АрутЮновА-ФидАнян, Армяно-византийская контактная зона... 62. As a result, and given the traditional rivalry between the two nations, the mere memory of the form of Christianity once shared by Georgians and Armenians (and Albanians) was suppressed in Georgian sources, and in fact, practically all the extant Georgian literature originates after the split. During the reign of Husraw II Parwēz, the Sasanian Empire favored the Monophysites rather than the traditionally tolerated Nestorian branch of Christianity (dubbed «the Church of Persia»), presumably, because of the influence of Šìin, the Armenian wife of the King of Kings immortalized by Persian poets (see В. Г. Луконин, Древний и раннесредневековый Иран. Очерки истории культуры (Москва, 1987) («Хосров II и Анахита», pp. 177-206) 205), so, in 614, after Jerusalem was captured by the Sasanian Persians, they tried to impose the anti-Chalcedonian leadership on all the Christians in their realm, including those in the territories conquered from the Byzantines. We know next to nothing about the effect this Imperial decision had in Georgia; however, in 625/6, when Heraclius and his «Khazar» allies besieged Tbilisi, the city was defended by its local Georgian Christian ruler subject to Iran, and by a Persian garrison under a Persian officer. It seems that the genuine account of these events was lost, if it ever existed in a written form in Georgian, because for the later Georgian readers the prospect that their ruler had probably abandoned what was seen since then as the core of Georgian identity, was deemed to be offensive (on traces of the pre-Chalcedonite Christianity in Georgia in the context of Jerusalemite traditions, compare interesting remarks in: Лурье, Из Иерусалима в Аксум через Храм Соломона... 177-178 and n. 101; as I tried to demonstrate (D. SHAPIRA, Armenian and Georgian Sources on the Khazars: A Re-Evaluation // Proceedings of the First International Khazar Colloquium (in press)), Georgian accounts about the joint Byzantine-«Khazar» siege of Tbilisi drew upon Armenian sources and were composed long after the events they describe, with the intention to conceal the anti-Chalcedonite character of the rulers' Christianity.

${ }^{20}$ Thirty five, in Armenian accounts.

${ }^{21}$ «After the Synod of Nicea» (325 CE), adds MS B; the reason for expulsion of Christians from a Christian Empire remains obscure. As to the date, that's the date the Georgian text of MK provides. There is pointless to stress again and again that the chronology of the events connected with St. Nino — or even with St. Gregory — is hopelessly wrong, but one could recall that Aristakes, the son of St. Gregory, attended, as Armenia's respresentative, the Nicean Counseil in 325. According to the Armenian sources of St. Nino's Vita, namely, the History of Agathangelos, the holy virgins fled from Diocletian, whose protégé Trdat was. 
rived in Armenia and stayed there, as properly to the «daughters of the bridal chamber of Christ», in the "garden booths» of the Armenian, still pagan, King Trdat. Few days later, the holy virgins were martyred by King Trdat, because of his limitless lust, on the day of Passover (the 15th of the first month, on Friday), and it was only St. Nino who survived among the rose thorns, because at this time the roses and almonds budded (MS B). ${ }^{22}$ The wording is a contamination of Ecclesiastes 12.5 and Song of Songs, 6.11, 7.13; «almonds» is taken from Ecclesiastes (Song of Songs has «pomegranades»), while the context of Song of Songs' passages may be easily understood as containing references to the «booths» and bridal chamber, with the contexts of Eccl. and Song of Songs 7.13 understood as speaking of (martyr) death. ${ }^{23}$ The martyrdom of the virgins in their bride rooms makes them, of course, the perfect brides of Christ, and we will return to this subject later. We can state here but in passing that the very developed flower imaginery in Nino's traditions has many Middle Eastern, including Syriac and Iranian, parallels and deserves a special study. As to the date of the martyrdom, obviously modeled upon the death of Jesus, one should note the remarkable emphasis on the features of the Jewish Feast of Tabernacles, whose motifs were early contaminated, in the Gospel tradition, with those of Passover (compare Jesus' entrance into Jerusalem, with hossanas sung and lulabs waven).

After her arrival (from Armenia) in Urbnisi, Kartli, St. Nino stays for a month with the local Jewish community there, at their bagini (sanctuary, synagogue), «because she spoke the Jewish language», as the text puts it; her

${ }^{22}$ According to the same MS B, St. Nino experienced a vision of a deacon descending from heaven, with an censer in his hand, which was spreading fragrant smoke; the deacon was receiving the ascending souls of the martyrs. We will return to this later. St Nino asked God why should she be abandoned amongst asps and vipers, but the Voice answered here that likewise shall be her own ascend, when all these thorns around shall become rose-leaves. This account, appearing also in KC 84-85, is ascribed in MK to Salome of Ujarma, one of the early pupils of St. Nino, who was said to be the daugther of Trdat of Armenia and the wife of Rev, son of Mirian of Kartli; she is said to be the authoress of those parts of MK most flavored with parallels to the Agathangelos Cycle; however, she is unkown to the Armenian tradition; moreover, her name is Jewish / New Testamental, a strange feature for a daughter of a pagan king; we even know that the members of dynasty of her father continued to bear pagan names for generations after the conversion; queens and princesses bore Iranian names as well, together with the majority of the bishops, cf. N. G. GARSOÏAN, Prolegomena to a Study of the Iranian Elements in Arsacid Armenia // Handes Amsorya. Zeitschrift für armenische Philologie XC (1976) 176-234 (p. 13-14 n. 34; reprinted in N. G. GARSOÏAN, Armenia Between Byzantium and the Sasanians (London, 1985) (Variorum Reprints) Paper N. X).

וונתרה בת צייון כסכה , בכרם. This wording, from a Christian point of view, fits entirely the setting. 
intention was «to learn the strength of their earth» (MS A, Šatberdi). But according to MS B, Čeliši, she first came to $\operatorname{Mc}^{c} \operatorname{xet}^{c} a,{ }^{24}$ the capital city of Kartli; while living there for three years, she was secretly praying in the brambling bush, located outside the walls, and she erected there a cross made of vine twigs (KC ignores this episode). Later this cross became known in Georgia as «the Cross of St. Nino», «the Vine-Cross» or «the Cross of the Branches» (jvari sasxlevisa), highly venerated by Georgians; ${ }^{25}$ as to the spot of Nino's prayer before the vine cross, on its place is now the altar of the Upper Church, being thus considered, together with the «Live-Giving Cross» transferred there later, the most sacred relics of the early Georgian Christianity.

Later on, she witnessed the statue of the supreme sword-bearing god of $\mathrm{Mc}^{\mathrm{c}} \mathrm{xet}^{\mathrm{c}} \mathrm{a}$, Armazi, ${ }^{26}$ having been shattered by rage of God, in accordance to Nino's prayer, during a pagan festival. People fled in turmoil, while Nino

${ }^{24}$ The Armenian author of uncertain date, Moses Khorenac $i$, mentions [R. W. THOMson, Moses Khorenats i. History of the Armenians. Translation and Commentary on the Literary Sources (Cambridge, Mass.-London, 1980) II. 86] Nunē, one of the scattered holy helpers of Rip'simē, as the one who escaped to $\mathrm{Mc}^{c}{ }^{c}{ }^{c}{ }^{c} \mathrm{a}$, the capital city of the Iberians. She is depicted as an auxilary to St.Gregory. The question of the genesis of the St. Nino legend and its relation to the Rip'simē / St. Gregory tradition is a complicated one and is still open.

${ }^{25}$ One cannot but get reminded of the Mandaean draf̌s $a$, which is a kind of cross with something similar to a tallith hung over it.

${ }^{26}$ Armazi's idol was erected under Parnavaz, the second Georgian king, in legendary times. The names of many ancient Georgian kings and their officials bore were of Scytho-Sarmatian origin (Ksefarnug, Saumarg, Vaxtang (kings); Radamist (prince), Sharagas, Zevax, Aspauruk (pitiaxš-s); Iodmangan (chancellor), cf. В. И. АБАЕв, Скифо-сарматские наречия // Основы иранского языкознания. I (Москва, 1979) 272 365 (p. 361, n. 33). In Scythian legends, as reported by Herodot, iv 62, their Ares was seen as an antique iron sword on a platform surrounded by a huge wood pile to whom prisoners were sacrificed, with their blood poured over the sword. Such a «temple» was said to have been placed in the capital of every district in the vast territories of Scythia. A legend with similar motifs was told in Western China about the origin of the local Scythian (Saka) Buddhist dynasty to Hsu'eng-tsang, a Chinese pilgrim ca. 640 C.E. in Uḍ̣̣iyâna (M. L. CARTER, A Scythian Royal Legend from Ancient Uḍ̣iiyâna // Bulletin of the Asia Institute 6 (1993) 67-78, p. 69). Though not without some Biblical (Genesis 2) impact, the sword of Armazd in $\mathrm{Mc}^{c} \mathrm{xet}^{\mathrm{c}}$ a must be of the same Scythian origin. The name of the supreme god of the ancient Georgians, Armazi, is generaly taken to be derived from the Iranian Ahūra Mazdå- (Н. Я. МАрР, Боги языческой Грузии // Записки Восточного Отделения Императорского Русского АрхеологИческого Общества 14 (2-3) (1902); С. С. КАКАБАДЗЕ, К воПросу о стоЛИЦе Древней Картли (Иберии) Армази-Мцхета // Эллинистический Ближний Восток, Византия и Иран (Москва, 1967) 112-123). There is however another opinion, deriving the name of this god from Asianic languages [Hittite etc.] (M. CERETELI, The Hittite Land, Its Peoples, Languages, History (Constantinopole, 1924) 84 [Georgian], who was unavailable to me; Ш. И. АмиРАНАшвили, История грузинского искусства. I 
found a beryl which was put in the idol's eye. Then she rested on the mountain's ridge near the old castle where stood a booth, sagrilobeli, built by king Bratman, under whom Jews first arrive in $\operatorname{Mc}^{c} x e^{t} a$, according to MK. The booth, sagrilobeli, stood near the tree of brinj ${ }^{27}$ accacia. ${ }^{28}$ There she prays before the cross she has erected, and it was on the sixth day of the month when Immanuel shew on Mt. Tabor the likeness of His Father to the heads of the living and the dead, it is, the Feast of Transfiguration. ${ }^{29}$ (We should remind, to return to this later, that at Jesus' transfiguration, he, Moses and Elijah sat in the booths.) It is important to note that in the preceding and following scenes, roses, vines and other plants and flowers are frequently referred

(Тбилиси, 1944) 56; А. И. БолтуновА, К вопросу об Армази // Вестник древней истории 4 (1949) 235ff.; Г. А. МЕликишвили, К истории Древней Грузии (Тбилиси, 1960). According to M. Andronikashvili, Studies in Iranian-Georgian Linguistic Contacts. I (Tbilisi 1966) 548, 570, Armazi is an Iranian loan of the Achemenian epoch, from Old Persian A(h)ūra Mazdâ: «the Georgian language avoids congestion of consonants at the end of a word - Vaštasab from Vištâsp, Luarsab from Lōhrasp, Artavaz from Artavazd, Armaz from Aramazd, etc.» (the case of Artavaz from Artavazd is especially important here). The name of the second god, Zaden-i, was connected to the Iranian word Yazata-; it seems that the particular Georgian form is from Parthian Plural, (*ya-)zadèn, which is very close in meaning to the Middle Persian yazdân, sometimes used in a singular sense.

27 The Georgian word, which means also «rice» and is Persian in origin, can be explained as the result of a mistranslation of Syriac ' $r z$ ' or Arabic ' $r z$ ('arzâ / 'arz. means «cedar», 'urzâ / 'urz means "rice»).

${ }^{28}$ The tree from which the Biblical tabernacle was built, Hebrew šittâh, was generally rendered as accacia.

${ }^{29} \mathrm{Cf}$. Mat 17.1 and parallels: the transfiguration of Jesus took place six days after the events descripted previously in the New Testament text; on Transfiguration, cf., e. g., H. Riesenfeld, Jésus Transfiguré... (København, 1947) (Acta Seminarii Neotest. Upsaliensi XVI); J. A. McGuckIN, The Transfiguration of Christ in Scripture and Tradition (Lewiston/Queenston, 1986) (Studies in the Bible and Early Christianity 9); M. SAUCHOT, L'homélie pseudo-chrysostomienne sur la Transfiguration CPG 4724, BHG 1975... (Frankfurt am Main-Bern, 1981) (Publications Universitaires Européennes. Sér. XXIII. Théologie 151); F. BEST, The Transfiguration. A Select Bibliography // Journal of the Evangelical Theological Society 24 (1981) 157-161; Joie de la Transfiguration d'aprés les Pêres d'Orient / Textes présentés par Dom Michel Coune (Abbaye de Bellefontaine, 1985) (Sp. orientale 39); F. REFoulÉ, Jésus, nouveau Moése, ou Pierre, nouveau Grand Prêtre? // Revue théologique de Louvain 24 (1993) 145-162; B. E. REID, The Transfaguration. A Source — and Redaction-Cultural Study of Luke 9:28-36 (Paris, 1993) (Cahiers de la Revue biblique 32); J. E. Fossum, The Image of the Invisible God. Essays of the influence of Jewish Mysticism on Early Christianity (Freiburg Schweiz-Göttingen, 1995) (Novum Testamentum et Orbis Antiquus 30). I am extremely grateful to V. M. Lourié for these and other references, as much as for his sensitive and sympathetic reading of two versions of this paper and sharing with me his ideas and knowledge. 
to. ${ }^{30}$ Then, led by a vision of a man of light, St. Nino goes down to the Royal Garden, ${ }^{31}$ where she finds, under cypresses, «a place of vines prepared with love». ${ }^{32}$ St. Nino works wonders and experiences visions. Then Queen Nana

${ }^{30}$ It seems that Nino, whose name alliterates with that of Anahit, the pagan / Zoroastrian patroness of Armenia, was born to explain the costums of the Christianized Vardavar, corresponding to the Christian feast of Transfiguration as celebrated in Georgia. This pre-Christian feast was placed in $551 \mathrm{CE}$ on the seventh Sunday after Pentacost (becoming thus the second «Šabhu'oth», Weeks), coinciding, in this way, with the ancient Zoroastrian New Year, Nawasard, celebrated by then on August the 6th. The Vardavar' / Nawasard / Transfiguration celebrations are characterized by sprinkling of water, offering branches and flowers to the Virgin Mary and consecration of vines. In some places people used to drink beverages in gardens. J. Russell has noted that «such practices may go to the worship of Anahit and Nanē» (the underlining is mine), noting also the role played by roses in Armenian festivities on that day (the name Vardavar, according to Russell, contains this word as its first element, which was, however, frequently used in Iranian as the term for any flower; see J. R. Russell, The Etymology of Armenian Vardavar // Annual of Armenian Linguistics 13 (1992) 63-69 (p. 69)); cf also S. H. TAqIZADEH, The Iranian Festivals Adopted by the Christians and Condemned by the Jews // Bulletin of the School of the Oriental and African Studies 9 (1940-1942) 632-653 (pp. 643-647). V. M. Lourié has noted, however, in a letter, that as to Vardavar, «its Armenian date (7th week after Pent.) corresponds to the ancient (and even modern Nestorian) date of the Twelve Apostle Feast (translated in the 6th century to June 29); so, we have to take vard- in another (homonymic) meaning of "(magical) word" combined with a component with a meaning of "fire". So, Vardavar has to be etymologized as "word(s) of fire", alluding to the Apostolic preaching after the tongues of fire at the Pentecost, and the later (Armenian) etymology through the meaning of "rose" is a pure popular etymology" (В. М. ЛурьЕ, Около Солунской легенды. Из истории миссионерства в период монофелитской унии // Славяне и их соседи. Вып. 6 (1996) 23-52). I believe Lourié is thinking of the first element of the word vardapet.

${ }^{31}$ Later, after his conversion by St. Nino, King Mirian built in this garden a wooden church (the Lower Church), with the Column of Cross of Light; this church was called «the holy of holies», as in Aksum. Only priests were allowed to enter this church and see the Cross hidden by a curtain (again, a situation very reminiscent of that in Ethiopia). Under King Arčcil and Archbishop Iona this column was transferred to the Upper (Gareubani) Church, whose altar was on the previous place of St. Nino's «brambling bush».

32 The sagrilobeli of Bratman as standing near the Brinj is mentioned, in MK, in the account of Sidonia. In the version of KC 92.13-14, she sat under the brinj [the Armenian version of the Georgian text: brinç] (accacia) tree, where king Bartam (Bratman in MK) made shade [sagrili]; as in MK, it was there that she made her cross. Then, St. Nino goes down to the Royal Garden (where King Mirian will have later built the Lower Church), where she finds, under cypresses, a place of vines prepared with love. This motif seems to be a variation of the episode from the flight of St. Rip'simē and her companions, when they lived in wine-presses (sac'nexelt'a venahisat'a) in the royal garden in Dvin (KC 82.10). 
converts in the brumbling bush of St. Nino, and later, King Mirian, while going hunting in the forests, is said to have lost his way in the mountains, darkness has befallen on him, but God turned King's mind to truth and light and he knew God. The King, believed by the people of $\mathrm{Mc}^{\mathrm{c}} \mathrm{xet}^{\mathrm{c}} \mathrm{a}$ to be lost and most probably dead, returnes to his city in peace, welcomed by the Queen and the people and preceedes directly to the brumbling bush, where St. Nino was praying at that hour as usual. There he aknowledged God, converted and built churches in the brumbling bush of St. Nino and in the place of his garden. More visions are described, with a Column of Light made of a Lebanon cedar descending from heavens to his proper place in the church of the royal garden. The Column of Light, or Life-giving Column, became renown for its many wonders and salvation, later to be hidden from the sight by a wooden box (kibot) built by Mirian. Then three crosses are made and erected in the church, and all the inhabitants of the city have seen every night a cross of fire crowned with stars descending from the heaven and standing above the church, etc.; more similar appearences are described in our text later. ${ }^{33}$ Then, as is well known, more churches were built in $\operatorname{Mc}^{c} x{ }^{c}{ }^{c} a$, given the names of landmarks in Jerusalem and its vicinity, ${ }^{34}$ a practice not unusual on the early stages of Christianization in different countries, with the aim to transform a pagan city into a new Jerusalem. ${ }^{35}$

In KC 93.17-94.1, it is a small bush under the pine trees, *planted /prepared for the Lord (cf. also Thomson, Rewriting Caucasian History... 102, n. 96), babilo ars mc'ire naãut'a k’ueše saup’lo šezavebuli / šemzadebuli [gamomğeblad].

Outside the walls she finds a hidden place in bramble bush (maqoulovani) and prays there; the booth of a guard is mentioned. In the KC (94.8) version, it is a thick bramble bush (brc'ami maqualisa) outside the city walls, or, in the Armenian version, in tamarisk groves [THOMson, Rewriting Caucasian History... 102]. In the consequence, the altar of Upper Cathedral Church (Samtavro) was to be built at that place (which became known as Ninos maqoulovani, «St. Nino's bramble bush»). She experienced there visions described by quotations from Song of Songs 3:10, 5:12, $2: 16$.

${ }^{33}$ E. g., after the Cross of Glory was established during the third week of the Passover, across the Aragua, not far from $\mathrm{Mc}^{\mathrm{c}} \mathrm{xet} \mathrm{t}^{\mathrm{a}} \mathrm{a}$; after the Pentacost, two miracles occured; the description of the «second miracle» occured to the Cross is a variation of the «burning bush motive» contaminated with Habbakuk 3:9.

${ }^{34}$ See, $e$. g., TARCHNIŠVILI, Sources arméno-géorgiennes de l'histoire ancienne de l'église de Géorgie... 29-50 (pp. 49-50).

${ }^{35}$ On building of Zions in the 5th century, cf. cf. Лурье, Из Иерусалима в Аксум через храм Соломона... 172ff. et passim; for the Ethiopian parallels to the stories about the 50 virgins martyred (in Edessa by Julian the Apostate), about the always curtained Column of Light, with the text of Abgar' Letter on it, standing in the church of Mary in Roha (Edessa) / Lalibela, cf. ibid. 177ff.; Lourié (ibid. 178 n. 101) remarks that one is tempted to translate the Ethiopian name of the Column of Light, ‘Amdâ Berhân, into Russian as Sveti C‘xoveli, Georgian for «Life-giving Column»! 
There can be little doubt that these texts are modeled on Agathangelos: thrown into a pit for many (thirteen or more) years by Trdat, because of his refusal to worship Anahit, pagan Armenia's patroness, St. Gregory survived, however. After having massacred the holy virgins, Rip'simē, Gayanē and others (in vat-stores, or wine-presses; ${ }^{36}$ cf. Lamnt. 1.15, גת דרך ה' לבתולת בת יהודה, and Isaia 1:8 referred to above), King Trdat is punished, while going hunting, ${ }^{37}$ by being transformed into a likeness of a wild boar (this noble animal was perceived by Iranians as the bearer of the royal xvarnah, «glory» or «charisma»); ${ }^{38}$ he repents, seeks remedy, and St. Gregory heals the King, having baptized him. Thereafter, St. Gregory had a vision, in which he saw the heavens open, and a blaze of glory ( sotokat $^{c}$ ) covers the earth, with Jesus descending with a golden hammer in his hand, with which he struck the earth. Then a golden Column of Glory arose, surmounted by a cross, later called «the Cross of Glory». Three smaller red crosses of light were around the big one, their bases were the color of blood, the columns were of cloud and the capitals of fire; above these St. Gregory saw a great temple with a golden throne surmounted by a cross as well, with a stream flowing from the temple and forming a lake. From the four columns, above the crosses, marvelous vaults fitted into each other, and above these was a canopy (xoran $)^{39}$ of cloud

Cf. also B. М. Лурье, Три Иерусалима Лалибелы. Интерпретация комплекса церквей Лалибелы в свете данных его Жития // Warszawskie Studia Teologiczne XIII (2000) [2001] (= Miscellanea Aethiopica Reverendissimo Domino Stanislao Kur septuagenario professori illustrissimo, viro amplissimo ac doctissimo oblata) 117 140. On Georgian texts of the Letter of Abgar, cf. now N. Chkhikvadze, The old Georgian Versions of The Epistle of Avgar: Analysis, Text, Glossary // Gza sameupo [The Royal Way] 1/4 (1996) 32-72.

${ }^{36}$ The Arabic version published by Marr is more implicit on that point than the present Armenian Agathangelos: fi ma șirati fi-l-karm.

${ }^{37}$ There is vast literature on the sacral and ceremonial aspects of royal hunting in Iran and Armenia, cf. e. g., N. G. GARSOÏAN, The Locus of the Death of Kings: Iranian Armenia - The Inverted Image // The Armenian Image in History and Literature / Ed. R. G. Hovanissian (Malibu, Calif.-Undena, 1981) 27-64 (pp. 49ff.; repr. in GarsoÏAn, Armenia Between Byzantium and the Sasanians... Paper N. XI).

${ }^{38}$ On Trdat's tranformation into a boar, see N. G. GARsoÏAn, The Iranian Substratum of the 'Agat'angełos' Cycle // East of Byzantium: Syria and Armenia in the Formative Period. Dumbatron Oaks Symposium, 1980 / Ed. N. G. Garsoïan, Th. F. Matthews, R. W. Thomson (Washington, 1982) 151-189 (p. 153ff.; repr. in GARsoÏAn, Armenia Between Byzantium and the Sasanians... Paper N. XII).

${ }^{39}$ It was observed (МАрр, Крещение армян, грузин, абхазов и аланов... 150) that the text of Agathangelos substituted here the older Armenian vran by the newer xoran. Both Armenian words go back ultimatively to Iranian *vi-dâna; besides Armenian vr'an, Middle Persian wyd'n / wy'dn, Parthian wyd'n, Christian Sogdian (from Middle Persian) $w y^{\prime} n$, Baluchi gidân, etc., here belong also old Judaeo-Persian (in Sefer Pitron Torah) wy’n, Classical Persian ky’n (kiyân), in the sense of «tent» and 
in the form of a dome. The larger golden column means the Primacy of Armenia, and the smaller red columns stand for the virgin martyrs Rip'simē, Gayanē and others. Then St. Gregory builds a church on the model of the temple seen in the vision and calls it Ečmiajin, «the Only-Begotten has descended». The point of the story to prove that the Armenian National Church, called later "Gregorian», was commissioned by Jesus and is thus independent from the See of Caesarea; no less important is the ascertion that Armenia became officially converted before the Milano Edict. However, it is evident that while the vision described in Agathangelos is modeled on the vision of Constatntine contaminated with the appearance of the Cross under Constntius on May 7, 352, the visions described in the Georgian texts cannot go directly to the latter and are of secondary character, being dependent on the Armenian version. ${ }^{40}$

The oldest account on St. Nino, named, however, simply captiva, is found in Rufinus; in MK and KC, too, St. Nino is spoken frequently of as «a captive and foreigner». ${ }^{41}$ Rufinus' account was based on the information received from Bacurius, a Georgian prince and a Byzantine general (comes domesti-

«tent-like celestial sphere», and gorân, used in the sense «a bundle of crops», «so called because of its tent-like sphere», using Navabi's explanation (for $r$, compare Armenian $v r \times a n)$. In Judaeo-Persian, along with $w y^{\prime} n$, other forms are found as well, such as $g y^{\prime} n$ in the Vatican Pentateuch, identical with the mu'arrab form ky'n (kiyân, *giyân, and the hybride gwy'n in the London Pentateuch, both rendersing Hebrew 'ohel, «tent», with by' $n$ in other translation). See D. SHAPIRA, Judeo-Persian Translations of Old Persian Lexica: A Case of Linguistic Discontinuity // Persian Origins Early Judaeo-Persian and the Emergence of New Persian. Collected Papers of the Symposium, Goettingen 1999 / Ed. L. PAul (Wiesbaden, 2003) 221-242, spec. 228.

${ }^{40}$ D. ShapIRA, Old Georgian Echoes of the Armenian Agathangełos Cycle (forthcoming). Cf. interesting insights in В. М. ЛурьЕ (иеромонах Григорий), Видение св. Григория Просветителя: сошествие небесной скинии на Новый Сион // http: //hgr.narod.ru (Список работ); compare now also M. van EsBroecк, L'opuscule sur la Croix d'Alexandre de Chypre et sa version géorgienne // Bedi Kartlisa 37 (1979) 102-132 (pp. 129-131).

${ }^{41}$ See F. Thelamon, Païens et chrétiens au IVe siècle. L'apport de l'Histoire Ecclésiastique de Rufin d'Aquilée (Paris, 1981) 85-122, where the relevant Latin text is given, translated into French, with a very good analysis; for an English version, see now The Chruch History of Rufinus of Aquileia... 20-23; cf. also B. MARTIN-HISARD, Jalons pour une histoire du culte de Sainte Nino (fin IVe-XIIIe s.) // From Byzantium to Iran. Armenian Studies in Honour of Nina G. Garsoïan / Ed. J.-P. MAHÉ, R. W. Thomson (Atlanta, GA, 1997) 53-78, pp. 62-64; La Narratio De Rebus Armeniae / Edition critique et commèntaire par G. GARITTE (Louvain, 1952) (CSLO 132, Subsidia 4); cmp. TARCHNIŠVILI, Sources arméno-géorgiennes de l'histoire ancienne de l'église de Géorgie... 29-50 (the table on p. 32 is repeated in Thelamon, Païens et chrétiens au IVe siècle... 92). 
corum and dux limitis) serving in Palestine between 380-394 CE, who is frequently mentioned in both $\mathrm{MK}$ and $\mathrm{KC}$. Numerous episodes occurring in MK and KC (and in [pseudo-]Movsēs Khorenacci dependent on the relevant Georgian versions) have their exact correspondences, even in their chronological order, in Rufinus. The captiva passes her life in praying in her cellula («booth, hovel»), her prayer heals a child and then the Queen, the King refuses to convert, but one day he goes hunting and «a thick darkness fell upon the day», his companions flee, he has lost his way, then he vows in his heart to be Christ's servant, the daylight comes back and the king returns happily to his city; he converts, and a church is having been put up; then a wooden column «which so many machines and people had been unable to move, suspended upright just above its base, not placed upon it, ${ }^{42}$ but hanging about one foot in the air». ${ }^{43}$

Though it is not difficult to see the similarities between the three accounts (the Georgian ones, that of Agathangelos, and that by Rufinus / Bacurius), there are significant differencies, too: the oldest source, that on Rufinus, mentiones a wooden column hanging in the air, but does not mentioned any Cross or Crosses, who later became so important in the Georgian accounts and in that of Agathangelos; the Georgian traditions are uncertain about the number of the Crossess and even confuse the Cross with the Column of Light and with the wooden column put up in the church. ${ }^{44}$ The Vine Cross of St. Nino is absent from Rufinus, too; however, she is told to dwell in a cellula, a word meaning a dwelling place propriate for a captiva, but it may have also some religious overtones; of course, it might easily refer to a booth in a garden. I will not deal here the motifs of the Crosses appearing in a vision ${ }^{45}$ but rather concentrate myself on some episodes found in MK and absent from Rufinus and Agathangelos.

${ }^{42}$ For the wording, compare Lament 4:6.

${ }^{43}$ The translation by Amidson (The Chruch History of Rufinus of Aquileia... 22).

${ }^{44}$ Cf., e. g., TARChNišVILI, Sources arméno-géorgiennes de l'histoire ancienne de l'église de Géorgie... 36-37.

${ }^{45}$ Rufinus' account on the convertion of Georgia was inserted into an Armenian translation of Historia Ecclesiastica of Socrates, made by Philon of Tirak in 696; there a mention of the «Cross of $\mathrm{Mc}^{c} \mathrm{xet}^{\mathrm{c}} \mathrm{a}$ » is already found; see PEETERS, Les débuts du Christianisme en Géorgie... 46-47; P. Peeters, A propos de la version arménienne de l'histore de Socrate // Annuaire de l'Institute de philologie et d'histoire orientales et slaves 2 (1934) 647-675 (pp. 650-651); TARCHNIŠVILI, Sources arménogéorgiennes de l'histoire ancienne de l'église de Géorgie... 35. One may suggest that the emphasis on the crosses in these rather early Armenian and Georgian traditions should have been seen also in the context of the extensive veneration of the cross in the Persian («Nestorian») Church; on the Georgian-Nestorian context in the mid-5th century, cf. PeETERs, Jérémie, évèque de l'Ibérie perse... 5-33. 
I take it for granted that these episodes were intented to be not without some mystical implications. They deal with garden, bramble bush, booth, and the place prepared with love in the royal garden, all of them without parallels in Agathangelos (though in the last case, a contamination is possible or even inspiring). Now, I would present my attempt at interpretation.

\section{II \\ Soneh and Sinai}

The word translated here as «bramble bush» (maqoulovani) which is outside the walls, where St. Nino prayed and erected her Vine Cross, is the Old Georgian word for «burning bush» revealed to Moses on Mt. Sinai / Horeb. The Hebrew for «burning bush» is səneh, ${ }^{46}$ translated batos by the Greek; the botanic identification remains a problem. ${ }^{47}$ It is to be noted that Sinai was extremely closely associated, in Middle Eastern traditions, with Moses' burning bush not only because the vision of the burning bush took place on this mountaine, but also because of similarity in sound. One might take it for certain that the original Hebrew Biblical text played with the alliteration between səneh and Sinai, and, actually, the name of the mountain may mean «the mountain of the burning bush». ${ }^{48}$ In the Qur’ânic verses, surah 23.20, Sain $\hat{a}^{3} / \operatorname{Sin} \hat{a}^{3}$, Sinai, and surah 95.2, $\operatorname{sinīn}$, meaning, according to many Islamic authors, both Sinai and burning bush, show how close both notions were confused, probably not without some Christian and/or Jewish impact. In the latter Christian tradition the «burning bush», batoj, became identical with Mt. Sinai, symbolizing the Old Testamental revelation.

In the New Testament, there are two slightly different usages of the word batoj [Lk 6.44, thornbush, elsewhere in the New Testament — bush], rendered by the New Testament Greek, having been based on the Septuagint text, invariably batos, which, according to Liddell-Scott, ${ }^{49}$ is «bramble-bush» or «wild raspberry»; the Armenian version, so close to the Georgian one, has in Luke 6.44 (thornbush) moreni, «blackberry, mulberry», moreni being «bri-

${ }^{46}$ It must be a non-proper Hebrew [i. e., a dialectal] form of $*_{s} \bar{e} n$, «tooth» > «thorny,» in Aramaic and Syriac sanyâ ['].

${ }^{47} \mathrm{Cf}$. The New Brown-Driver-Briggs-Gesenius Hebrew and English Lexicon with an appendix containing the Biblical Aramaic (Massachusetts, 1979) 702: a thorny bush, perh. blackberry bush, Löw: rubus fruticosus, Meissner: blackberrybush; a kind of Rubus, Rubus sanctus.

${ }^{48}$ This was, in fact, the view expressed by some medieval Jewish commentators (Nachmanides to Deutoronomy 1.6; Narboni to «Guide to Perplexed», I I.32; R. David Kimche, Sepher ha-Šorâšìm).

${ }^{49}$ An Intermidiate Greek-English Dictionary, founded upon the seventh edition of Liddell and Scott's Greek-English Lexicon (1889'1 Oxford, 1991). 
er, bramble, blackthorn, pyracantha» $;^{50}$ this moreni is used in the Armenian Bible also in Exodus 3.2 (burning bush). To the best of my knowledge, it is the Old Georgian tradition only which identifies the «burning bush», $i . e$., the Greek batos, as «bramble bush» (maqoulovani). ${ }^{51}$

The bramble bush of St. Nino was located outside the Royal Garden and outside the walls. This must symbolize, from the Christian point of view, the Old Testamental deprival of Grace, as the Royal Garden stands for Paradise: who is the King if not God? This «Old Testamental» wilderniss (outside of the walls $)^{52}$ of the Sinai's brambling bush is, however, gracely shaded by the presence of the cross, and not simply a cross, but a cross of vine, with vine being almost proverbial symbol of Israel. It is in place to remind here that in Eastern Christendom, vines are consecrated at the feast of Transfiguration, being perhaps not only a reflection of the natural course of things, but also a hidden allusion to the transfer of Grace from Israel to Israel. ${ }^{53}$

\footnotetext{
${ }^{50}$ On this word, cf. H. HüBschmann, Armenische Grammatik. I (Leipzig, 1897) 394.

${ }^{51}$ Cf. Yerušalmi, Macasērōth 1.2, ענבי סנה.

${ }^{52}$ Compare Heb 13.12; I owe this reference to V. M. Lourié.

${ }^{53}$ Compare the account of Abiathar in the version of MK on the baptism of the princes (Georgian for «baptism, conversion to Christianity» means in fact «illumination, enlightment», cf. note 9 above) xolo sax̣li eliozisi iq’o kalaksa šina dasavalitsa, iq'o qarsa moguetisasa, mt'quarsa zeda. da iq'o mcirey bagini, samarx̣voi

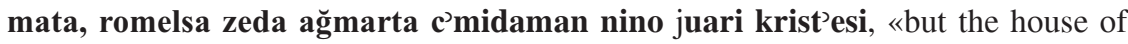
[the Jewish «priest», one of St. Nino's pupils] Elioz was in the western part of the city, where there was the Zoroastrian gate, near the river Kura (Mt'quari). There was a small house of worship, their resting place, upon which St. Nino erected the Cross of the Christ». This resting place (samare) means in fact «grave» (samarxi, «burial place, funeral expenses»; samarxo, «lenten fare»), so the Cross of the Christ was in fact erected on Jewish graves (said to be, by a characteristic «Freudian slip», «their place of worship»); the purpose of this erecting a cross was, apparently, redeeming the straying souls of the Jewish dead (an analogy to this Christian practice can be easily seen in the recent arising of a cross, by Catholics, in Auschwitz; I should note, in passing, that this small episode is sufficient to repell, once and forever, the widespread and confusing notion that St. Nino's Vita may reflect some historical Jewish past). This place became later known as «the illumination / baptism of the princes». But this cross is a tree, samotxeyi in Old Georgian, and this word was used for «Paradise» (like Armenian draxt), cf. D. SHAPIRA, An Aramaic-Irano-Armenian Note // Iran \& Caucasus II. Research Papers from the Caucasian Centre for Iranian Studies, Yerevan / Ed. G. Asatrian (Teheran, 1998) 92-101, see 95; on the other hand, in Armenian (gerezman), Persian and many Iranian and non-Iranian dialects of the area, the old Iranian word for «Paradise» became to be used in the sense of «tomb, grave», cf. ibid. 97, n. 15. So, establishing a cross on the graveyard means in Old Georgian, tautologically, leading to Paradise.
} 
However, the said above seems to not contradict Ephrem's view in his Hymns of Paradise, ${ }^{54}$ where Paradise is typified by Sinai. At the summit of Paradise, seen as a mountain, stands the Glorious One (Jesus). Upon the heights (rawmâ[[]]) is where Moses resides. In Ephrem's description, Aharon corresponds to the slopes (gabbē[]]) of Paradise, while the people of Moses are compared with the lower slopes (šphülē [']) of Paradise. ${ }^{55}$ A text from Ephrem illustrative of this is as follows:

A symbol of the divisions

in that Garden of Life

did Moses trace out in the Ark

and on Mount Sinai too (HdP II.13). ${ }^{56}$

This implies that Ephrem ties together «Garden (of Life)», «tabernacle» ${ }^{57}$ and «Mt. Sinai», with the notion of «bramble bush» apparently included into the idea of «Sinai». Apparently, the Biblical festival of Tabernacles was reintrpreted by Christians as that of the Burning Bush. The «tabernacle» he keeps in mind is that connected with both «Mt. Sinai», i.e., that built by Moses in the wilderness, and with the «Garden (of Life)», Paradise, realized as «abode». Now we go straight into the «tabernacles of Paradise», rajskie kušči

III

\section{Miškân and sukkâh}

The booth built by king Bratman / Bartam where St. Nino rested after the statue of Armazi was shattered is designated as sagrilobeli [the version of KC called this structure simply sagrili, «shade»], which could be seen to be a specific Jewish or Judeo-Christian word taken from an ancient Judeo-Georgian parlance, used by Judaizers (or even Jews?) as a substitute for the Aramaic $m l l$, sukkâh, the ritual booth built by the Jews at the festival of Tabernacles, or, Sukkōth. ${ }^{58}$ The Aramaic word is formed from the root ȚL, «sha-

${ }^{54}$ I am very thankfull to Christopher Back for calling my attention to Ephrem's material and sharing with me his ideas.

${ }^{55}$ Similar material is found also in Jewish sources (no Jesus, of course); cf., e. g., Mekhilta d'Rabbi Sim'on b. Jochai: Fragments in Geniza Cairensi digessit apparatu critico, notis, profatione instrucxit / Ed. J. N. Epstein, E. Z. Melamed (Jerusalem, 1956) 145 (19.24); Mechilta D'Rabbi Ismael cum variis lectionibus et adnotationibus / Ed. H. S. Horovitz, I. A. Rabin (Frankfurt, 1928-1931; Repr.: Jerusalem, 1960) 218 (par. 4).

${ }^{56}$ St. Ephrem the Syrian, Hymns of Paradise / Trans. by S. Brock (Crestwood, NY, 1990).

${ }^{57}$ «Ark», «tent», «tabernacle», all of them stand stand for the same object; on the problem of translation, cf. N. D. OsBorn, Tent or Tabernacle? // The Bible Translator 41/2 (1990) 214-221.

${ }^{58}$ On sukkâh, cf. R. PATAI, Man and Temple in Ancient Jewish Myth (London, 1947) (see index); J. Rubenstein, The Sukka as Temporary or Permanent Dwelling // 
dow», which means also «to cover»; the Georgian word sa-gril-obel-i is from «shade», gril-, thus rendering only one meaning of the Semitic word (shadow). In Semitic and Iranian both «shadow» and «canopy, pavilion» were frequently rendered by the same word ${ }^{59}$ though from the architectonical point of view it is not entirely clear what exactly this sagrilobeli was, I suppose that sagrilobeli was not different from what is called now in Georgia by the word talvari; and in this case, Judeo-Persian sâyah would fit perfectly the Old Georgian usage of sagrilobeli. ${ }^{60}$

It is not implied here that the Georgian word sagrilobeli was coined especially by Jews in order to render their Aramaic word for «ritual booth»; they or, Kartlian Judaizers - rather adopted an existing Kartvelian word. I suppose that the Jews - or, Kartlian Judaizers — did not use of talavari, Modern Georgian talvari, because it had already been appropriated by Christians and/or Manichaeans. ${ }^{61}$ As a matter of fact, the word talavari seems to be more suitable for all the additional religious overshades of «booth».

Hebrew Union College Annual 64 (1993) 137-166; J. L. Rubenstein, The Symbolism of the Sukkah // Judaism 43 (1994) 371-387; Y. NAGGan (Gank), Arbacat ha-minim ke-qorban ba-halakhah šel HaZaL // Dacat 49 (2001-2002) 5-33, esp. $15-20$.

${ }^{59}$ Sogdian sayâk means both «shadow» and «canopy, pavilion», with Christian Sogdian texts rendering Greek $\sigma \kappa \eta ́ v \eta$ by $s y^{\prime} q$ (cf. É. BENVENISTE, «Mots d'emprunt iraniens en arménien // Bulletin de Societé Linguistique 53/1 (1957-1958) 55-71, see 68 n. 4; Sogdian shares many rare isoglosses with Armenian, and, in our context, it is not without interest to note that «synagogue» is called in Armenian, Georgian and Sogdian «bagini $[i]$ of the Jews»). New Persian sâyah, «shadow», has not only the normal meaning of «shadow», but that of «canopy, pavilion» as well, cf. W. B. HENNING, The Desintegration of the Avestan Studies // Transactions of the Philological Society (1942) 40-56 (= Acta Iranica 15; W. B. HennING, Selected Papers. II (TéhéranLiège, 1977) 151-167) 50 (=161) n. 1; while the semantics of the Sogdian word have developed perhaps under a Syriac impact, those of the New Persian word wereinvariably influenced by Arabic maz̧allah, itself from Aramaic mațâlâ. But especially itelling is Judaeo-Persian evidence quoted by Henning in the same note: sâyah renders Hebrew sukkâh, «booth» (Isaiah 1.8, 4.6 etc.) and molünâh, «hut» (Isaiah 24.20; compare Rufinus' cellula!). On other Jewish words for «canopies», «pavillons» and «tents», cf. SHAPIRA, Judaeo-Persian Translations of Old Persian Material... 228-229.

${ }^{60}$ Slavonic sen', «shadow», means also «booth, tabernacle», and is attested in Mt. 17, exactly in the context of a «tabernacle of Moses, Jesus, and Elijah» (the origin of Russian kušča, which is the word used to render this concept now is unknown to me); V. M. Lourie drew my attention to the fact that Slavonic sen' is also used as a sort of a pavillon/canopy on the relics in the churches. I was unaware of this latter meaning of the word.

${ }^{61}$ On Manichaean missions to Armenia, cf. Henning's remarks in G. Haloun, W. B. Henning, The Compendium of the Doctrines and Styles of the Teaching of Mani, the Buddha of Light // Asia Major 3.2 (1952-1953) 184-212, p. 206 and n. 9; 
on the mission to Georgia, cf. W. B. Henning, Two Manichжan Magical Texts, with an Exursus on the Parthian ending -ēndēh // BSOAS 12.1 (1947) 39-66, p. 49, n. 1, and Haloun, Henning, The Compendium of the Doctrines and Styles of the Teaching of Mani... 206; S. N. C. LIEU, Manichaeism in Mesopotamia and the Roman East (Leiden, 1994) (Religions in the Graeco-Roman World / Ed. R. vAN DEN BROEK, H.-J. W. Drijvers, H. S. Versnel. 118) 35. Manichaeaism was spread in Georgia, as well in Armenia; Manichaean Parthian M216b and M2230 texts mention the land Waručân, recounting the story of the conversion of Hbz' the šâh of Warūč; the country was identifyed with Wlwc'n in Šâhpuhr's Great Inscription, Iberian in the Greek version. Henning (W. B. HennING, "Waručân-Šâh» // Journal of the Greater India Society 11.2 (1945) 85-90) distinguished between the two Waručân-lands; later (cf. Henning, Two Manichæan Magical Texts... 49, n. 1), Henning tended to see here, nevertheless, Georgia. Cf. now W. Sundermann, Die mittelpersischen und parthischen Turfantexte als Quellen zur Geschichte des vorislamischen Zentralasien // Prolegomena to the Sources on the History of pre-Islamic Central Asia / Ed. J. HarmatTA (Budapest, 1979) 143-152; 145, W. Sundermann, Mitteliranische manichäische Texte kirchengeschichtlichen Inhalts (Berlin, 1981) (Berliner Turfantexte XI) 45-49; W. SundermanN, «Studien zur kirchengeschichtlichen Literatur der iranischen Manichäer // Altorientalische Forschungen 13 (1986) 40-92, 239-317 (pp. 281-282); S. N. C. LIEU, Manichaeism in the Later Roman Empire and Medieval China (Tübingen, 1992²) 106. An Uigur Manichaean text, U237 + U295, P. ZIEME, Manichäischtürkische Texte (Berlin, 1975) 21 (441-463), 50-51, has hvza wruž-an il-ig I šad baliqda ärti, "The King (and?) šad of Waručân was in the city», translated in LIEU, Manichaeism in Mesopotamia and the Roman East... 35. A Sogdian Manichaean text 18224, published in Sundermann, Mitteliranische manichäische Texte kirchengeschichtlichen Inhalts... 45-49, text 3.4, cf. also LIEU, Manichaeism in Mesopotamia and the Roman East... 26, 31-32, n. 30 on p. 32ff., mentions a Manichaean mission to Ryb’n, *Rēwân, identified by Sundermann with Maḥōzē d-'Arēwân in Beth-Garmai, but by Russell (J. R. Russell, Manichaean Apostolic Mission to Armenia? // Proceedings of the Third European Conference of Iranian Studies held in Cambridge, 11th to 15th September 1995. Part 1: Old and Middle Iranian Studies / Ed. N. SimsWilliams (Wiesbaden, 1998) 21-26 with Erevan in Armenia (who argued that this was the Christian Armenian tradition about Sts. Thaddeus and Bartholomew that influenced the Manichaean narrative on Mâr Gabryâb's mission). In Fihrist, a Manichaean Risâla Arminnīya was mentioned, cf. SundERMANn, Mitteliranische manichäische Texte kirchengeschichtlichen Inhalts... 45, an apostolic epistle to the Armenian Manichaeans. An isolated folio (2 pages) separated from the Berlin codex P. 15997 contains a historical summary of the Manichaean mission in Armenia, Azerbaijan, and to the oases of the Syrian desert, from Sâhpuhr I to Narsē I, cf. M. TARDIEU, La diffusion du bouddhisme dans l'empire kouchan, l'Iran et la Chine après un Kephalaion manichéen inedit // Studia Iranica 17 (1988) 154-182 (p. 158 n. 8); a fascimile edition was published in S. Giversen, The Manichaean Coptic Papyri in the Chester Beatty Library II: Homilies and Varia. Fascimile Edition (Cahiers d'orientalisme 15) (Geneva, 1987) Pls. 99-100. 
In Georgia nowadays talvari is used for a vineyard booth, an indispensable feature in every country house. ${ }^{62}$ Another meaning of the word is «trellis», as in Iranian dialects. ${ }^{63}$ Unlike sagrilobeli, which is purely Georgian, Old Georgian talavari (Modern Georgian talvari) is a Parthian loan word, known also in Armenian as taławar.

It is impossible to decide whether the word entered Georgian via Armeniaca or independently. ${ }^{64}$ But the meaning attested for the word in the early Georgian literature is somewhat different from the modern («trellis») usage. ${ }^{65}$ In both Armenian and Georgian the word tatawar, talavar, talavari, means «tabernacle», especialy as the designation of the ritual booth built by Jews at the Feast of Tabernacles, being thus synonimical with sagrilobeli. As to the the semantical range of meanings of talavari, it seems to be a «Bibleism», copying Hebrew / Aramaic miškân / maškənâa, ${ }^{66}$ meaning both «tabernacle» and «booth; tent; abode».

In an apocryphical composition, the «Book of Adam and Eve», ${ }^{67}$ whose date and provenance are still disputable ${ }^{68}$ there is an incident preserved only

${ }^{62}$ I owe this information to Prof. K. Lerner.

${ }^{63}$ As Benveniste (Benveniste, Mots d'emprunt iraniens en arménien... 67-68), has shown, in different Iranian dialects (Gīlâk", Velâtrū, Tâjīkī), tâlâr signifies both une construction de pieux ou de planches destinée à étayer des ceps de vigne and une grande salle. Georgian authors regard talvar in Azeri, where it has both meanings, as a Georgian loan word. However, it might be an old Iranian substratum word.

${ }^{64}$ AndroniKashvili, Studies in Iranian-Georgian Linguistic Contacts. . . 171, 272 173, derived the Georgian form from Parthian talvâr, via Armeniaca; unattested in J. GIPPERT, Iranica Armeno-Iberica. Studien zu den iranischen Lehnwörtern im Armenischen und Georgischen. I-II (Wien, 1993) (Verlag der Österreichischen Akademie der Wissenschaften).

${ }^{65}$ Cf. Luke 9.33, Mattew 17.4.

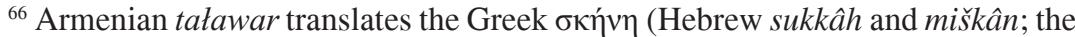
Armenian translation was made from Syriac circa 415, according to the native tradition); Old Georgian has talavari for $\sigma \kappa \eta ́ v \eta$ in the New Testament, but karavi for sukkâh, as in Leviticus 23.42; cf. BenVENISTE, Mots d'emprunt iraniens en arménien... 68; Bielmeier (R. BIELMEIER, Zu iranischen Lehnwörter im Georgischen und Armenischen // Sprachwissenschaftliche Forschungen. Festschrift für Johann Knobloch / Ed. H. M. Ölberg, G. Schmidt, H. Botlien (Insbruck, 1985) (Insbrucker Beiträge zur Kulturwissenschaft 23) 33-42, p. 35) reports of Old Georgian talari, «Laube»; as to the form and the meaning, cf. New Persian tâlâr.

${ }^{67}$ The Armenian name is «Penitence of Adam», cf. M. E. Stone, The Penitence of Adam / Ed. R. Draguet (CSCO 429-430. Scriptores Armeniaci 13-14) (Leuven, 1981).

${ }^{68}$ Cf. M. E. Stone, A History of the Literature of Adam and Eve (Atlanta, Georgia, 1992) (Society of Biblical Literature. Early Judaism and its Literature. Number 03). Cf. also Literature on Adam and Eve. Collected Essays / Ed. by G. AnDERson, M. Stone, J. Tromp (Leiden, 2000) (Studia in Veteris Testamenti Pseudepigrapha 15). 
in Armenian and Georgian, ${ }^{69}$ where the word taławar / talavari appears. The so-called «Books of Adam and Eve» survive in a variety of languages and in diverse forms; none of these books derives from any of the others, ${ }^{70}$ but the Armenian and Georgian ${ }^{71}$ versions are of a great importance. ${ }^{72}$ Those two last versions kept a very old and genuine Jewish tradition: when the first human couple was expelled from Paradise, they built a booth (tałavar in Armenian, talavari in Georgian), in the east of Eden (Armenian / Georgian 1:1; Latin, 1:1, without specification of location).

One could suggest that in the archetype of this composition, the first human couple were bereft of the Divine Glory of šakhinâh, which was their garments, according to Jewish midrashic texts. This Jewish tradition was known to Armenian sources, sometimes regarded as «heterodox». In the Paulician treatise «The Key of Truth» it is stated: $:^{73}$ «furthermore he [Jesus] then put on that primal raiment of light which Adam lost in the garden», naes and zgec'aw zlousi $\neg \bar{e}$ p patmoučann zarjajÔin zor koroys Adamn i draxtin. ${ }^{74}$ This reference to «that primal raiment of light» in the context of Adam's story in the Paulician tradition is important, as, according to Garsoïan, ib., pp. 155, 233, the oldest strata of the Paulician tradition treats «the story of Adam and Eve in its traditional form», on the one hand, and represents the «original Christianity received from Syria», on the other. It is also plausible to suggest that the miškân, talavar, was supposed to substitute the šokhinâh (which is formed from the same root) that they had lost.

${ }^{69}$ For the Armenian text, cf. Stone, The Penitence of Adam...; for the Georgian text, cf. C. K K $^{\mathrm{URC}} \mathrm{U}^{\mathrm{I} I \mathrm{IDZE}}$, Adamis Apokrifuli cxovrebis kartuli versia // Philological Studies 1 (1964) 97-136 [Georgian] and J.-P. MAHÉ, Le Livre d'Adam géorgien // Studies in Gnosticism and Hellenistic Religion / Ed. R. van den Broek, M. J. Vermaseren (Leiden, 1981) 227-260.

${ }^{70}$ Stone, A History of the Literature of Adam and Eve... 6.

${ }^{71}$ It is not unprobably that there existed an Armenian intermediary for the Georgian composition which was older that the extant Armenian, though the evidence for an Armenian Vorlage of the Georgian is not strong, cf. Stone, A History of the Literature of Adam and Eve... 38, n. 106; 39.

72 The Georgian version was even taken to be the best witness to the Adam Book, cf. Stone, A History of the Literature of Adam and Eve... X-xi, 69; J.-P. MAHÉ, Notes philologiques sur la version géorgienne de la Vita Adae // Bedi Kartlisa 41 (1983) 51-65 (p. 65).

${ }^{73}$ Cf. N. G. Garsol̈an, The Paulician Heresy. A Study of the Origins and Development of Paulicianism in Armenia and the Eastern Provinces of the Byzantine Empire (Paris, 1967) 153 n. 6.

${ }^{74}$ On the meaning of that last Armenian word and its etymology, cf. SHAPIRA, An Aramaic-Irano-Armenian Note... 95 \& 97, n. 15. 
Building this talavar-booth thus was an attempt to return to the conditions of the lost Paradise, ${ }^{75}$ where the rightous ones «sit, when their crowns are on their heads, enjoying from the Divine Splendor», ${ }^{76}$ «in their booths», ${ }^{77}$ as it is obvious from the next description of Adam and Eve's quest for food, being not just a «housing solution»: Adam and Eve are not described in this composition as Kulturträger of any sort or civilizing inventors.

In the Babylonian Talmud we are told that «the Holy One Blessed Be He, will make seven booths for every single righteous one». ${ }^{78}$ It was noted that the mention of «wreaths» ${ }^{79}$ in Jubilees' description of the first Feast of Tabernacles, held by Abraham, is striking as it implies soteriological dimensions of booth-dwelling ${ }^{80}$ In traditions about the Rechabites, the righteous heterodox Hebrews, legends about whom were very early connected with the traditions about the Lost Tribes, we have some soteriological hints as reflected in the mention of «tabernacle»: in the Aramaic Targum to Jeremiah the Hebrew word for tents, 'ohel, in which the Rechabites dwell, is rendered by maškən $\hat{a},{ }^{81}$ exactly as in Bar Koni report about the Proto-Mandaeans ${ }^{82}$ and in their own genuine tradition, cf. changing of sukkâh by 'ohel in Damascus Document VII $14-16 .^{83}$

75 Note that Bartman's sagrilobeli was placed outside the Royal Garden, on a mountainous (Azazel-like?) ridge. In the Islamic lore, especially, among heterodox groups of Western Iran and Kurdistan, Adam and Eve are said to be settled by Gabriel, in the Garden, in a green tent (khaimah).

${ }^{76} \mathrm{Cf}$. Berrakhoth 17a: «The righteous are sitting and enjoying from the Splendor

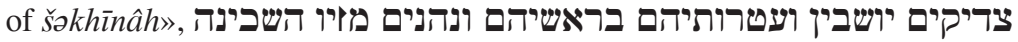

77 TB Baba Bathra 75. Hence the otherwise badly attested rajskie kušč $i$ ?

${ }^{78}$ Baba Bathra 75: עתיך הקב"ה לעשות שבע חופות לכל צךיק...

${ }^{79}$ Hebrew עט טרות :*...they should celebrate it and dwell in booths and set wreaths upon their heads and take leafy boughs and willows from the brook», Jubilees, XVI 31. stephanos tēs zwēs (Rev. 2.10, 2 Tim. IV 8) is known also from the Babylonian Talmud, Megillah 15b.

${ }^{80}$ Cf. R. H. Charles, The Book of Jubilees (London, 1902) 118, n. 30. For this work, see now C. J. VANDERKAM, The Book of Jubilees (Sheffield, 2001).

${ }^{81}$ Vulgata uses urbes tabernaculorum for ערי מסכנות in Exodus 1.11; it means,

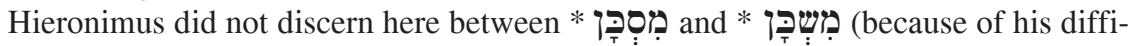
culty to discern between $s$ and $\check{s}$ ?) and for him how to render the two Hebrew words into English, cf. N. D. Osborn, Tent or Tabernacle? // The Bible Translator 41.2 (April 1990) 214-221.

${ }^{82}$ Bar-Koni's account on Manichaeaism is to be found in H. PognON, Inscriptions mandates des coupes de Khouabir (Paris, 1898) 125-131 and in A. ScHER, Theodore bar Konai, Liber Scholiorum (Paris, 1912) (CSCO srip. syri, ser. II. 66) 311-318.

${ }^{83}$ For the text and translation cf. now M. Broshi, The Damascus Document Reconsidered (Jerusalem, 1992). 
The Jewish commentator Rashi to Hosea 12.10, «[I] will yet make thee to dwell in tabernacles», ${ }^{84}$ makes clearer the point about the eschatological functions of sukkâh when he writes «I will arise from your midst savants ... as in the days of the first $m \bar{o} \bar{e}^{-} d$ (period / tabernacle) when Jacob was a pious man, tabernacle-dweller» ${ }^{85}$ and the Targum has «I will make you to dwell in mišknayy $\hat{a}^{\prime}$ (Plural) ${ }^{86} »$. So in the World to Come the pious ones will dwell in Tabernacles. It is worth notice that the Messiah will give to the Gentiles «a small commandment, the commandment of sukkâh» (mișwah qallah ... usukkâh $\left.\breve{s}^{e} m a \hat{h}\right),{ }^{87}$ thus the deed attributed to St. Nino may reflect this particular Jewsih tradition. The parallels from the Jewish Intertestamental literature are important for better understanding of St. Nino's sagrilobeli. The Talmudic parallels are also important, as they preserve ancient traditions, but may seem less relevant. However, the spiritualization of «tabernacle» is to be found also in the Mandaean tradition. As is well known, all the Mandaean cult is held by crowned priests called «kings», ${ }^{88}$ malkiia, in ritual huts maškniia ${ }^{89}$ nowadays called mand". The Proto-Mandaeans were called $m \check{s} k n y^{\prime}$ by Theodore bar Koni. ${ }^{90}$ But miškân has several meanings in Hebrew whence the Mandaean form derives: it is not only an old [and Aramaic] word for «tent», or a word for «tabernacle» (clearly similar in meaning to «Tabernacle of the Congregation», 'ohel $m \bar{o}(\bar{e} d)$, it is also a general and archaic term for «dwelling place» and even for «palace» (like New Persian tâlâr). Aramaic Targums used ma lâlâ for both 'ohel and miškân; this Aramaic word, formed from roots for «to cover» and «shade» was suitable for contexts where

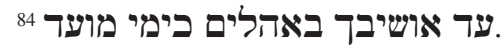

אעמיד מתוכך תלמידים חכמים כיפי מוער הראשון שהיה יעקב איש תם 85

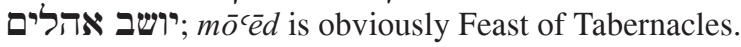

אותבינך במשכניץ כיופי קדם 86.

${ }^{87}$ Cf. Abodah Zara 3a.

88 «Angels» or «apostles» also seem to be a propriate rendering based on a popular etymology, especially possible in Mandaic, with a very complicating re-groupping of roots in this Aramaic dialect. It this context, I dare to make a suggestion: were not the presupposed links of Jesus' community with the Proto-Mandaeans or with one of similar sects using similar semantics the reason why his pupils called themselves «apostles»? Cf. also D. SHAPIRA, Anuš and 'UArâ Revised: Notes on AramaicIranian Linguistic Interaction and Mystical Traditions // Kabbala: International Journal for the Study of Jewish Mystical Texts 6 (2001) 151-182.

${ }^{89}$ The Mandaic maškan / maškna, «a cult-hut» was studied by G. FuRLANI, I Termini Mandei per Tempio, Santuario e Chiesa // Studi Orientalistici in Onore di Giorgio Levi Della Vida. Vol. I (Roma, 1956) 341-360 (pp. 348-352, inter alia).

${ }^{90}$ Cf. K. Rudolph, Die Mandäer, I. Prolegomena: Das Mandäerproblem (Göttingen, 1960) 32, n. 5; cf. now D. KRUisheER, «Theodor Bar Koni’s Ketâbâ d-Eskolyon as a Source for the Study of Early Mandaeism // Ex Oriente Lux. Jaarbericht van het Vooraziatisch-Egyptisch Genootschap 33 (1993-1994 [1995]) 151-169.
} 
«Clouds of Glory» and «canopy», huppâh, were used. It is exactly in this sense that the word sagrilobeli is used in the Old Georgian Vita Nino, one of the oldest Georgian texts, from gril-, «shade» (like the Aramaic $m t l l$ ', Arabic mazallat-un, Hebrew sukkâh and səkhâkhâh), comparable in function to that of talavari.

In Nestorian writings ganōnâ['], ${ }^{91}$ formed from a root meaning «to cover», ${ }^{92}$ «a wedding chamber», ${ }^{93}$ is closely connected with the Tree of Life and the Spring of Paradise; the decriptions of the wedding hut in the Acts of Thomas (whose Manichaean relations are well established) and of the Mandaean bride chamber are identical; the original word for $v u \mu \varphi \omega v$ in the Manichaean Psalms, where we now have the Coptic MaNCy€ $\boldsymbol{\lambda} \in \boldsymbol{\epsilon} T$, must be *ganōnâ['].94

This word, in the form of $g n w n^{2}$, is found in Mandaic; 95 one notes that this connection to the Tree of Paradise might have been inspired by Song of Songs $1: 17$, «the beams of our house[s] are cedar, and our rafters of fir / cypres-

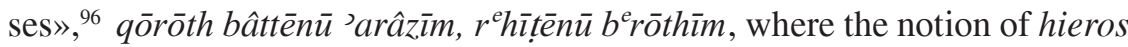
gammos is obvious. ${ }^{97}$ It must be noted that ganōnâ['] means «a covered hid-

${ }^{91}$ I had presupposed that the talvar word in Parthian must be identical in meaning also with the Syriac ganōnâ['], and indeed, as Professor W. Sundermann (Berlin) kindly informed me, he found [after our conversation on this Parthian word] a new Manichaean Parthian version of the New Testament fragments where the Parthian talwâr stands for the Syriac ganōnâ['].

${ }^{92}$ At least, as a popular etymology by contamination with an existing root; according to G. Widengren, Culture Contact, Cultural Influence, Cultural Continuity, and Synkretism. Some Views on My Prevoius Work // Religios Synkretism in Antiquity. Essays in Conversation with Geo Widengren / Ed. B. A. Pearson (Missoula, Montana, 1975) 1-20; p. 3, Akkadian ganūnu < Sumerian ganun > Syriac ganōnâ['].

${ }_{93}$ The motif of Heavenly Bridegroom is stressed in the Armenian version of KC and in Teachings of St. Gregory, cf. R. W. Thomson, The Teaching of St. Gregory: An Early Armenian Catechism (Cambridge, Mass. 1970) § 441, and Thomson, Rewriting Caucasian History... 88.

${ }^{94}$ Cf. G. Widengren, Mesopotamian Elements in Manichaeism (Uppsala-Leipzig 1946) (King and Savior II) 118-120.

${ }^{95}$ Cf. Ibid. 120, n. 1.

${ }^{96}$ Both trees mentioned in this verse pay important role in the accounts of St. Nino discussed in Part I of this paper.

${ }^{97}$ About ganōnâ ['], referring to hieros gammos, cf. also W. B. Henning, A Sogdian God // BSOAS 28.2 (1965) 242-254, esp. 242-244. In a Jewish wedding, the two to be married are standing under a Chuppah, huppâh, which imitates a tent, being the word used by texts quoted above in our context of tabernacle (it stands as a synonym for sukkâh); in Revelation 21.2-3, Jerusalem, which is the tabernacle, decsends like a bride ornated for her bridegroom; cf. TB Sukkah 2ab; cf. also the forthcoming Hebrew article by Michael Shneider, «Hieros Gammos in Potiphera House: "Joseph and Asenath", the Merkabah Literature and Sefer ha-Bahir». 
ing place», some kind of sukkâh, and, on the other hand, one should observe that in Old Georgian, the word for «tree» is used simply for «Paradise»..$^{98}$

Important is that both the Song of Songs context and that of the Adam Book and Manichaean ${ }^{99}$ Parthian fragments to be refered to below speak about a human couple, a man and a woman, in a context with nuptial, if not sexual, overtones. The imaginery of a wedding as a royal ceremony is common in the Eastern-Meditteranean tradition, and I believe that the designation of Mandaean priests serving in their tabernacles as «kings» might also have something to do with it, as the bridegroom is called «king» in all the Near-Eastern languages.

I believe that this episode with *talavar in the Armenian / Georgian versions of the Book of Adam and Eve is old and original. The better translation of the Parthian talavar would be «tabernacle, trellis», while in the Nino episode some other overtones may be traced. Nino was, after all, «the bride of Jesus», and there are indications that our *talavar word, being used in Georgian as synonymous with sagrilobeli, has had also some nuptial semantics. We will deal with this aspect also when we arrive to the third episode, that of the place «prepared with love», or, «prepared for flowers», siquarulod šemzadebuli.

But now we turn to the traditional Jewish Midrâš to Song of Songs 5.1 (ed. Donsky 1980, p. 126), «I came to my garden, my sister, my bride...»; the Midrâš explains the word «garden» as if it means «tabernacle» and connects it with the Divine Glory, šskhinâh. The word used here for «tabernacle» is from the same root as the word «garden», like the Nestorian-Syriac and Mandaic terms discussed above, while the normal Jewish word for «tabernacle» is from the same root as the word šakhinâh:

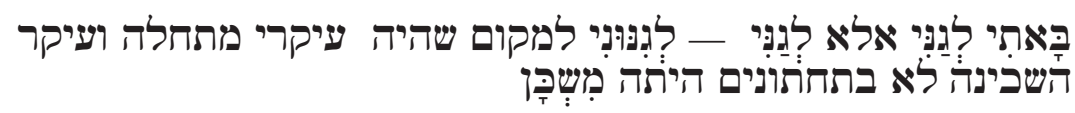

«I came to my garden... but «to my garden» means «to my tabernacle / bridal chamber», to the place where My origin used to be from the beginning. But was not the origin of the šakinâh from the beginning among the the Terrestials?» Later on, the text of the Midrâš makes it clear that šakhinâh it means is actually miškân, the tabernacle. This Jewish tradition has several Christian parallels, and it explains easily why St. Nino built her booth in the garden. Actually, the word in question means also «bridal chamber» and is well attested in Syriac (cf. above). Jewish texts, too, do play on this meaning of the word, as well as on the words «my sister, my bride». ${ }^{100}$

${ }^{98}$ Cf. ShapIRA, An Aramaic-Irano-Armenian Note... 92-101.

${ }^{99}$ References to Adam are found in the Manichaean text in Greek called «Mani Cologne Codex», 48,15-50,7, cf. A. Henrichs, L. Koenen, Der Kölner Mani-Kodex (P. Colon. inv. nr. 4780). Edition der Seiten 1-85 // Zeitschrift für Papyrologie und Epigraphik 19 (1975) 1-85 (pp. 48-51).

${ }^{100}$ WaYiqra Rabbah 9.6, BaMidbar Rabbah 13.2. 
In another Passage in Ephrem, HdP III.5, 13; XV.8, the Tree of Knowledge is described as the sanctuary curtain or veil, or, better, the inside of the palace (Syriac appay $\operatorname{tar}^{\prime} \hat{a}\left[{ }^{\prime}\right]^{101}$ ), while the Tree of Life is the inner sanctuary or holy of holies (HdP III.5, 14; Syriac qadūš qudšé[']; compare the tree of the Life-giving Column of Light installed — and wrapped in a veil - in the holy of holies of the $\mathrm{Mc}^{\mathrm{c}} \mathrm{xet}$ a church or in Aksum and Lalibela!). We remember that building a *talavar, a sukkâh, was caused by the first human eating from the Tree of Knowledge, and in $\operatorname{Mc}^{c} x e t^{t} a$, the altar of the church was built on the place of the brinji tree. The Tree of Knowledge is half-way up the mountain of Paradise, while the Tree of Life is at the summit of Paradise (HdP III.2). Paradise symbolizes both the Temple and the Church, and vice versa, of course: Tabernacle is equal to Paradise. ${ }^{102}$

The Manichaean milieu in Georgia was already refered to. Warūčân (Iranian for Georgia) is mentioned in an early Manichaean text in Iranian. In a Manichaean Parthian text, which one may call «a Manichaean Qəduššâh / Sanctus», ${ }^{103}$ we find: qwf'n d'lwwg 'wd $x^{\prime} n s^{\prime}{ }^{\prime}{ }^{\prime} n$ wyhm 'styg 'pdn 'wd tlw'r pd twgry'ng wyšmn'd 'hynd, «the mountains, the trees and the springs, the wide strong palaces ${ }^{2} p d n^{104}$ and $t l w^{\prime} r \mathrm{~s}^{105}$ will be joyful in You, $\mathrm{O}$ the Blessed One!». ${ }^{106}$

In another text ${ }^{107}$ we have: tlw'r bg'nyyg nywgr'n wyndynd ... 'wš cym 'st kyrbg cy $c^{\prime} r^{*} b w x t n$ gryw... «the well-doers found a divine $t l w^{\prime} r$... and because of this, that is the merit, which has to redeem the soul»; ${ }^{108} t l w^{\prime} r b^{\prime} m y n$ nxwyn ptbg (13) cyhrg 'st'nynd u wyšm'nynd o (14) nyšgyn pdmwg pdmw-

${ }^{101}$ In Iranian and Aramaic [and in Hebrew of Esther], the word for gate means also palace.

${ }^{102}$ As it is also in Breshit Rabbah 48.10 (sukkâh of Isaiah 4.6 understood as Paradise) and Mekhilta de-Rabbi Yishmael, Be-Šallạ̣ (haqdamah).

${ }^{103}$ M. Boyce, A Reader in Manichaean Middle Persian and Parthian (Leiden, 1975) (Acta Iranica. $2^{\mathrm{e}}$ Série 2) VII. 104 (M 10 R 10 - V 22; E. WALDSCHMIDT, W. LenTZ, Die Stellung Jesu im Manichäismus (Berlin, 1926) (APAW, phil.-hist. Klasse) 126; cf. D. ShapIRA, Manichaios, Jywndg Gryw and Some Other Manichaean Terms and Titles // Irano-Judaica IV / Ed. Shaul ShaKed, AmNon Netzer (Jerusalem, 1999) 122 150.

${ }^{104}$ On this word, cf. now SHAPIRA, Judaeo-Persian Translations of Old Persian Material... 227-228.

${ }^{105}$ Cf. also W. B. Henning, The Book of Giants // BSOAS 11 (1943-1946) 52-74 (= Acta Iranica 15. W. B. Henning Selected Papers II (1977) 115-138) 73.

${ }^{106}$ Cf. Psalms 114:4,6.

${ }^{107}$ bc, see Boyce, A Reader in Manichaean Middle Persian... 110-111, M33 II R i with M 367 V, W. B. Henning, Mitteliranische Manichaica aus Chinesisch-Turkestan III // Sitzungsberichte der Preussischen Akademie der Wissenschaften 27 (1934) 846-912, h 55-66; 912, n. 1.

${ }^{108}$ Cf. ShapIRA, Manichaios, Jywndg Gryw... 122-150. 
cynd u (15) jywynd y'wyd'n 'ndr whyšt o rwcšs 'st, «they receive ('st'nynd) as their Nature $(\mathrm{cyhrg})$ the original splendour ${ }^{109}$ of the radiant Palace $\left(t l w^{\prime} r\right.$ $b^{\prime} m y n$ ) and are joyful. They put on the resplendent (nyšgyn) Garment, and live for ever in Paradise». ${ }^{110}$ Written by Roščad, the text gives the promise of original splendor (which Adam and Eve were deprived with their expulsion from the Garden of Eden) after the return to Paradise. There the primeval splendorous $t l w^{\prime} r$ will be granted back for ever.

The most striking example of spiritualization of $t l w^{\prime} r$ is found in another Manichaean Parthian text, quoted by Boyce in the Introduction to her Hymns' edition, when the goal of the departed soul is a tabernacle of Logos in the Eternal Paradise, as described in this Parthian text, T II D 138 37-46: «Lay hold upon salvation and freedom from hurt. They prepare for you a tabernacle of the spirit. ${ }^{11}$ Enter into the kingdom befo're the Father of greatness, and in his presence become endued with your own piety, stillness and purity».

It seems that the same idea as that of the righteous ones sitting in the splendid Gardens that we meet in an-Nadīm's account about the Manichaean Paradise. The wording in the Fihrist's Arabic account of the Manichaean Paradise, ${ }^{112}$ «the Gardens of Light», sounds as if an-Nad"m has quoted an original Manichaean text verbatim: y'ty 'lsdyqwn mn 'lgn'n 'ly dhlk 'lnwr fyglswn fyh thm yt 'glwn' 'ly mgm' 'l'hh fyqwmwn hwl tlk 'lghym, «then the Electi will come from the Gardens of Paradise to that light, in which they will be seated. They will hasten to the gathering deities and stand around the Hell».

We have to remember that the whole concept of Paradise ${ }^{113}$ is an Iranian one, while Persian Gardens are renowned for their specific atmosphere; they

${ }^{109}$ nxwyn ptbg; *patitapataka, M. Boyce, Sadwes and Pesus // BSOAS 13 (19491951) 908-915; p. 915, n. 3, where Henning is quoted.

${ }^{110}$ Ibid. 915, Appendix (12). This text appeared as «bp» in M. BoyCE, Átaš-zōhr and Ab-zōhr // Journal of the Royal Asiatic Society (1966) 100-118, see 120-121; the context speaks about the first human couple and the Fallen Angels / Watchers, known from the Henochic tradition.

111 The underlining is mine. The translation is by Boyce (M. Boyce, The Manichaean Hymn-cycles in Parthian (Oxford, 1954) (London Oriental Series 3) 19, cf. n. 3); the underlined words are $t l w^{\prime} r w^{\prime} c^{\prime} f r y y d$, while $w^{\prime} c^{\prime}$ fryyd is rendered, ib., p. 196, as «created by word, spiritual» (Henning).

${ }^{112}$ F. G. FLÜGEL, Mani, seine Lehre und seine Schriften (Leipzig, 1862) 72; translated in B. Dodge, The Fihrist of al-Nad"m. A Tenth-Century Survey of Muslim Culture. 2 vol. (New York-London, 1970) Vol. II. 797.

${ }^{113}$ An Iranian loan, meaning «a garden», «an enclosure», «fenced-in [garden]», *pari-daēza > Greek parádeisos. New Persian pâlēz, Armenian $p^{`} \operatorname{art}^{`} \bar{e} z$, Kurdic pâr'ēs, Hebrew pardēs, Aramaic pardəsâ, Arabic (Pl) farâdis > firdaus; Old Turkic borduz, «orchards, melon plantations», K. H. Menges, The Turkic Languages and Peoples. An Introduction to Turkic Studies (Ural-Altaische Bibliothek, Fortsetzung 
must have some indispensable features, including running water (including artificial canals), lawns, trees and some outdoor buildings. ${ }^{114}$

This Parthian word in question, $t l w^{\prime} r$, is mostly rendered as «palace», so Boyce in 1949-1951, ${ }^{115}$ but in her Dictionary in $1977^{116}$ — «hall, tabernacle». Benveniste recognized the Armenian word as of Parthian origin ${ }^{117}$ but adopted Boyce's translation: $t w^{\prime} r b^{\prime} m y n$ - «radiant Palace». ${ }^{118}$ Otherwise, Benveniste used this word considering Armenian words for «tent». Gropp translated «Halle»; ${ }^{119}$ the word survived until these days as the Persian talwârah ${ }^{120}$ (from *talwârag), «a trellis, a scaffold», being maybe connected semantically to Arabic 'ařs, 'arǐšatun, «a tabernacle, a trellis, a pavillion», ${ }^{121}$

der «Ungarischen Bibliothek» / Hrsg. von O. PritsaK, W. Schlachter XV) (Wiesbaden, 1968) 167 [according to him, the word in Iranian itself is an old «Mediterranian» loan, cf. Basque barac, «garden», with bibliography]. Of course, pardēs in Hebrew does not mean «Paradise», nor does $p^{`} a r{ }^{\complement} \bar{e} z$ in Armenian (The Middle Persian word for the Garden of Paradise is bōstān [literally «the place of fragrance», whence Aramaic, Hebrew and Arabic bustān], used, e.g., in Bundahishn Ch. 30). On some Aramaic, Armenian and, especially, Georgian terms for «Paradise», cf. SHAPIRA, An Aramaic-Irano-Armenian Note... 92-101.

${ }^{114}$ Cf. V. Sackville-West, Persian Gardens // Legacy of Persia / Ed. A. J. ArberRY (Oxford, 1953) 259-291. It is worth noting that the Arabic raudatu 'l-firdaus is completely Iranian, althoug unattested in Iranian proper: raudah means «a cultivated wadi along a rivulet», from the Later Middle Persian rōdah/g. On gardens in Manichaean eschatology, cf. W. B. Oerter, Das Motiv vom Garten. Betrachtungen zur manichäschen Eschatologie // Manichaica Selecta. Studies Presented to Professor Julien Ries on the Occasion of his sevetieth Birthday / Ed. A. van TongerLoo, Søren GIVERSEN (Lovanii, 1991) 263-272.

115 Boyce, Sadwes and Pesus... 915.

${ }^{116}$ M. Boyce, A Word-List of Manichaean Middle Persian and Parthian (Louvain, 1977) (Acta Iranica 9a) 86.

117 É. Benveniste, Éléments Parthes en Arménien // Réarm NS 1 (1964) 1-39 (p. 28, n. 99). Cf. also Benveniste, Mots d'emprunt iraniens en arménien... 67-68. ${ }^{118}$ It seems that this translation was depending on the meaning of ' $p d n$. Compare SHAPIRA, Judaeo-Persian Translations of Old Persian Material... 227-228.

${ }^{119}$ G. Gropp, Mitteliranische Glossare und Index zu «Waldschmidt-Lentz» // Neue Methodologie in der Iranistik / Ed. by R. N. FRYE (Wiesbaden, 1974) 7-48 (p. 19).

${ }^{120}$ New Persian tâlâr, «hall», is another continuation of our MIr word. It seems that Gropp (Gropp, Mitteliranische Glossare und Index...) thought of this word when he translated talwâr as «Halle». A reference to the tâlâr-word was made in ANDRONIKASHVILI, Studies in Iranian-Georgian Linguistic Contacts... 273.

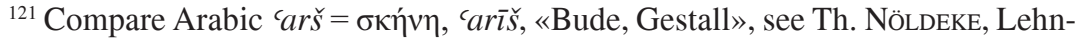
wörter in und aus Athuopischen // IDEM, Neue Beiträge zur semitischen Sprachissenschaft (Strassburg, 1910) 31-65, pp. 51-52. Cf. W. LeSlau, Comparative Dictionary of Ge'ez (Classical Ethiopic) (Wiesbaden, 1987) 71, who quotes South Arabian 'ars2, «shed, hut», and Soqotri 'arišs, «hut». For the usage of Arabic 'ařs in the sense of «booth, tabernacle», cf. M. J. KISTER, «A Booth like the Booth of Moses...». A Study 
itself from Aramaic, cf. the Hebrew 'arissâh and also another Hebrew byform for «espalier», 'arīs (according to Maimonides, «trellis» ${ }^{122}$ ); these Semitic words are used also, especialy the Arabic ones, as renderings of the Persian taxt, meaning both «a royal throne» and «a lecticulus» (cf. Syriac 'arsōnithâ, Luke 5.19). ${ }^{123}$ It seems that one of the reasons in choosing talwâr for Aramaic mațlâlâ was sound association (tal lṭ lâl $l^{124}$.

of an Early Had ith // BSOAS 25 (1962) 150-155: according to the early Muslim tradition, the Prophet refused to allow his followers to have built any masgid but «a booth like the booth of Moses, from a grass and wood ... with a covering of Moses», because the Day of Judgment is at hand ('arīš ka-'arī̌s Mūsā thumām wa-khašab fa'l-'amr 'a'gal min dhālika). This 'arī̌s Mūsāa, as described in the available sources, was a kind of trellis, in fact, a sukkāh, covered with palm branches but without ceiling; as to the ðcovering of Mosesñ, the hadith says that «when [Moses] stood up his head touched the ceiling». Cf. also G. R. Hawting, Origins of the Muslim Sanctuary at Mecca // Studies on the First Centuries of Islamic Society / Ed. G. H. A. JuYnbolL (South Illinois UP, 1982).

122 Kil’ayim 6:3: מקלעת שריגי גפן.

${ }^{123}$ Arabic 'arš was considered by many authors as «royal canopy».

${ }^{124}$ As to an etymology of talwâr, I see the problem in the first element $t l$-. The second element is clear, it is a vrddhi grade from the Iranian var-, «to cover», as in the word vara, «covering, shelter» (noted already in BENVENISTE, Mots d'emprunt iraniens en arménien... 69; cf. ANDRONIKASHVILI, Studies in Iranian-Georgian Linguistic Contacts... 273, who derived the word in question, tentatively, from Ossetic talm, «Ulmus»; on this word cf. АБАев, Скифо-сарматские наречия... 225-226); however, it hardly can be sustained; Benveniste speculated also on a probable link with Sanskrit tâla-, «palmier, arbre»). As to $t l$-, the Parthian $\mathrm{L}$ is very rare, being mostly from *R, but in some cases from (Parnian?) $\breve{S}$, so in the first part of the word in question one can see an irregular, East-Iranian, rendering of *tâš- «to build, to plane, to cut stones or wood». Cf. Parthian ' $z w g$ ’l, izgâl — from *uz-gauš, A. GHILAIN, Essai sur la langue parthe, son système verbal d'après les textes manichéens du Turkestan Oriental (Louvain, 1939) (Bibliothèque du Muséon 8) 66; В. С. РАСторгУеВА, Е. К. МолчАНОВА, Парфянский язык // Основы иранского языкознания. Среднеиранские языки (Москва, 1981) 147-232, p. 180; N. Sims-WiLliams, Eastern Middle Iranian // Compendium Linguarum Iranicarum / Hrsg. R. SснмIDT (Wiesbaden, 1989) 165-172, p. 167, commented on this shift: «non-Sogdian forms (in New Persian loan words from East Iranian Languages), however, include ... ispagol «seed of the fleawort»,

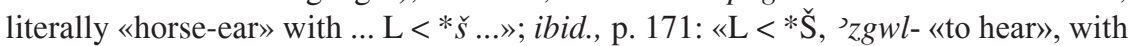
$\mathrm{L}<* \breve{S}$ as in Sangliči and Sariqoli ... Such forms as these have been plausibly attributed to the otherwise unknown language of the Parnians, a tribe of the «Scythian» Dahae...», quoting W. B. Henning, Mitteliranisch, Iranistik, Handbuch der Orientalistik. Erste Abteilung, vierster Band (Leiden—Köln, 1958) 92-94. Thus, one would

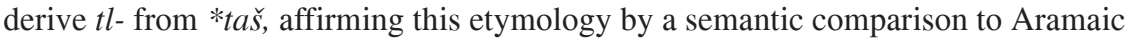
matlâlâ, «shelter, hut, booth», used as Aramaic for Hebrew sukkâh (cf. M. JASTROW, A Dictionary of the Targumim, the Talmud Babli and Yerushalmi, and the Midrashic Literature (New York, 1950) 768a), from țallēl, «to cover» [a sukkâh, i.a.]. It seems 
Thus, the Parthian talwâr was used, on semantic and etymological grounds, as an Iranian ${ }^{125}$ equivalent of Aramaic *maškənâ / mațlâlâ. It is not impossi-

that this Aramaic verb was used also for «to cover with wood», «to screen» (compare the Targum to 1 Kings 6.9, wyspn 't hbyt, cf. Jastrow, p. 537b) [Hebrew tall"th, «tallith, talles, praying shawl», «*a covering», is from the same root, with additional contamination of the roots for «to hang», tâlâh and țlal; as to tallēl, the Hebrew word used in Nehemia 3.15 is an Aramaeism]. As an alternative etymology of talwâr, a comparison to the second element of the Manichaean Middle Persian $b^{\prime} r g$ ťs, «a strong wall» (cf. W. B. Henning, A List of Middle Persian and Parthian Words // BSOS 9/1 (1937) 79-92, p. 88), may have been suggested. Here the order of the two elements is inverted; however, the derivation of $b^{\prime} \mathrm{rg}$ from Avestan vara- is questionable, cf. I. M. Oranskis, Notes Irano-Slaves. Vieil Iranien VAR- / Russe Dialectal VAR // Acta Iranica 5 (Monumentum H. S. Nyberg) (1975) 139-143, p. 10. On the other hand, tala might be an old Iranian word: Finnish tala, Livonian talzəD, «šalaš, labaz», «Laube», were seen as an Indo-Iranian loan word (A. J. JoKI, Uralier und Indogermanen. Die ältesten Berührungen zwischen den uralischen und ingermanischen Sprachen (Helsinki, 1973) (Suomalais-Ugrilaisen Seuran Toimituksia 151) 324), but Gamkrelidze \& Ivanov (Т. В. ГАмКРелидзЕ, В. В. ИВАНов, Индоевропейский язык и индоевропейцы, реконструкция и историко-типологический анализ праязыка и пракультуры. Т. I-II (Тбилиси, 1984) 933, n. 2) saw here a Baltic loan word (Prussian talus, «ground»). Professor W. Sundermann informed me that while the second element of talwâr might be -var-, «cover», the first element perhaps is the Semitic tall, thus accepting my comparision to the Aramaic mat $l^{\circ} l \hat{a}[$ [']; however, such hybrid SemitoIranian word looks to me unlikely. Prof. Sh. Shaked, by an oral communication, proposed to reconstruct talawara as *tarna-vara-, «a moisten / freshy covering». I think this is a convincing etymology, keeping in mind what talwâr was; as to semantics, compare Song of Songs 1.16, 'aph 'ars'ênu råanânâh, «our trellis is fresh», which comes immediately before qōrōth bâttēnū 'arâzìm, rahìt ènū borōthìm, «the beams of our house[s] are cedar, and our rafters of fir». «Freshy shelter» seems to fit in a proper way the nature of the modern Georgian talvari as known. On Song of Songs function in Early Christian exegesis, cf. M. W. Elliot, The Song of Songs and Christology in the Early Church (Tübingen, 2000) (Studien und Texte zu Antike und Christentums).

${ }^{125}$ In passing, I would like to draw attention to a Persian phrase put in the mouth of the Georgian king and found in the St. Nino's Vita. The phrase reads:

hei hei raitmeboy xoZat stabanub rasul psarzad

hey hey raytmeboy xožat stabanub rasul psarzad,

rightly glossed $« \mathrm{O}$, rightly You say, $[\mathrm{O}]$ blessed queen, messenger of the Son of God», reconstructed as *hey hey râ(s)t mē b/gōw" xuja(s) ta šâh bânūg rasūl (i) pusar (i) "zad, where one has to compare the graphic forms: raytmeboy / *ra[s]t me boi and stabanub / *Sah banug. The phrase is in post-Islamic [and dialectal?] New Persian, as it contains the Arabic rasūl; the shift $b / g\left(m \bar{e} b / g \bar{o} w^{\prime \prime}\right)$ is known from several Iranian dialects; the shift $s t>t(r \hat{a}[s] t)$ is less known; on the contrary, there exists the shift $s t>s$, cf. Sh. SHAKed, Items of Dress and Other Objects in Common Use: Iranian Loanwords in Jewish Babylonian Aramaic // Irano-Judaica III / Ed. Sh. SHAKed, A. Netzer (Jerusalem, 1994) 106-117 (pp. 112-114). The form *banug is actually Middle Iranian (bânūg) rather than New Persian (bânū). 
ble that the Parthian Manichaean fragments where the word is used are reworking of an Aramaic original of the Book of Adam and Eve. Thus, St. Nino's booth was indeed a substitute for the paradisical Temple (like that seen by St. Gregory in his vision), an idea going back to Jewish sects of the Second Commonwealth Period, who opposed the establishment of the Jerusalem Temple, with this sectarian notion becoming so central in Christianity.

\section{IV \\ Vine, Love, Flowers...}

Now, let us turn to the third motif, the place «prepared with love», or, «prepared for flowers», siquarulad / saquauiled šemzadebuli, where the Lower Church was built after king Mirian's conversion (in KC 94.1, where the setting was slightly reworked, it became «the place of a small bush under pine trees, planted for the Lord» [saup 'lo šezavebuli ${ }^{126}$ ). In my opinion, this is a reference to a locus in the Biblical Song of Songs, 3.10, râșūph 'ahabhâh (King James' version: being paved with love), generally taken in the exegesis to refer to Solomon's Temple or to the Church. Both the immediate context and the whole setting of this episode in St. Nino's Vita fit the assumption that what we have here is a hidden Biblical quotation, one of so many in this work. However, the standard Old Georgian text of the Song of Songs reads here «love» (siquaruli [asultagan ierusalimisata]), not «flowers». We should turn to other old versions of the locus. The understanding of the verse by the Septuagint has no specific interest, because it renders the verse, one would say, mechanically, lithostrwton, agapēn ..., as the common post-Biblical meaning of the verbal root RÍP is indeed «to pave», and thus it was rendered by the Pešițtâ, roșīph bərahmtēh, going clearly after the Septuagint.

Long after the bulk of this paper was completed, I found a treatment of this phrase in a new book by RAYFIELD, The Literature of Georgia... 52, where J. GIPPERT, Zum Status des Mittelpersischen im südlichen Kaukasus (forthcoming), is quoted; there is a misprint in the reconstruction given in this otherwise fascinating book, namely, khugasta instead of *khujasta or *khuğasta; the translation given is: «rightly thou speakest, fortunate Queen and emissary of the Son of God». According to Rayfield anf Gippert, the phrase proves that the language of the rulers of Georgia at that period [or, at the period of interpolation; the codex is dated by 1000] was New Persian. Cf. also J. GIPPERT, Marginalien zur Nino-Tradition // Summe der Orthodoxie, Sonderheft. Festschrift für Fairy von Lilienfeld 3 (Berlin, 1997) 126-130. This passage was dealt with as early as in 1892 by N. Marr; cf. Н. МАрР, Хитон Господень в книжных легендах армян, грузин и сирийцев // al-Muzaffariyya. Сборник статей учеников профессора барона Виктора Романовича Розена ко дню двадцатиления его первой лекции (СПб., 1897) 67-94.

126 Thomson (Thomson, Rewriting Caucasian History... 102) noted that «this expression is difficult». 
But if one turns to two other translations based on later Jewish exegesis and closer in time to St. Nino's period, then, exactly as expected, one finds that the Aramaic Targum renders râșūph 'ahabhâh by țill min 'ilawēh [yath pârūkhtâ'], «covered (as a shadow) from above [by curtain]», ${ }^{127}$ and the Vulgate, which reflects Jewish understanding, reads caritate constravit, which is especially close to the Georgian reading.

It is to be observed that the verb used in the Targum is $t l^{\prime \prime} l$ (from the same root as $m a l^{\circ} l \hat{a}$, etc.), thus bearing specific connotations in the whole complex of perceptions about tabernacle. In other words, in this MK passage we have a reference to a Georgian translation of Song of Songs older than the extant one; this translation reflects Jewish exegesis, paralleled in the Targum and in the Vulgate. As to the reference to «flowers» in the Georgian variant reading, it is a later one, caused by phonic and graphic similarity (siquarulad / saquauiled) ${ }^{128}$ albeit we should recall again the flower imagination of the St. Nino Cycle.

To sum up: the three episodes dealt with here treat the perception of the tabernacle / booth; there are traces of Judaizing (or Jewish?) traditions in the Old Georgian Vita of St. Nino; in several cases, translations of the Biblical verses presented in this work are different from those known to us from any other Old Georgian translation, with the impact of Jewish exegesis manifest in other cases. And most important, all these features are younger than those found in the relevant account of Rufinus and Agathangelos. It seems to me plausible to suggest that these traditions, reworking the Agathangelos Cycle, while adding new elements unattested there, being, at the same time, a result of a delicate contamination with Rufinus' account on the nameless captiva, testify to the emergence of an anti-Armenian, ethno-oriented, tendency in the Georgian Church. And, as in so many other cases, Judaizing (or, pseudoJudaizing) overtones served to the end of consolidating of a national church.

127 The Jewish Aramaic translation of ahabhâh by pârūkhtâ['], «curtain» (of the Temple) may be not only exegetical, but may reflect a genuine linguistic tradition. It was noted by earlier scholars that in this context the Hebrew word does not mean «love», but designates rather some sort of ornated skin, cf. Atabic 'ihâb, «skin», 'ahhaba, «to prepare, to equip».

${ }^{128}$ However, it was perhapse also influenced by Song of Songs 5.13 and 6.2. The Georgian Biblical texts are based on multiple sources and have undergone constant revision and retranslation for textual and doctrinal reasons; among the oldest sources were Syriac, Armenian, then Greek; it was suggested that some of the Biblical books were translated from the Massoretic Hebrew text, especially Ezekiel, cf. RAYFIELD, The Literature of Georgia... 7. 


\section{«СКИНИЯ В ВИНОГРААНИКЕ»: \\ НЕКОТОРЫЕ (ИУАЕЙСКОГО ПРОИСХОЖАЕНИЯ?) \\ ОСОБЕННОСТИ \\ В АРЕВНЕГРУЗИНСКОМ ЖИТИИ СВЯТОЙ НИНЫ}

Автор рассматривает три эпизода из Жития св. Нины (сохранившегося в составе Обращения Грузии), связанных с восприятием «хижины / кущи / скинии». В некоторых случаях в трактовке этих эпизодов обнаруживаются отчетливое влияние иудейской и ранней иудео-христианской экзегезы, причем, иногда это влияние проявляется в особой редакции библейских цитат, более не известной из древнегрузинских переводов Библии. Представляется важным отметить, что эти элементы грузинского Жития св. Нины более поздние, чем параллельные им традиции, представленные у Руфина и Агатангелоса. По мнению автора, наиболее вероятное объяснение факта использования этих иудейских (или мнимо-иудейских) традиций в грузинской переработке агиографических традиций цикла Агатангелоса и сохраненного Руфином предания о безымянной «пленнице» заключается в желании укрепить тенденцию Грузинской церкви к самостоятельности и независимости от церкви Армении. 